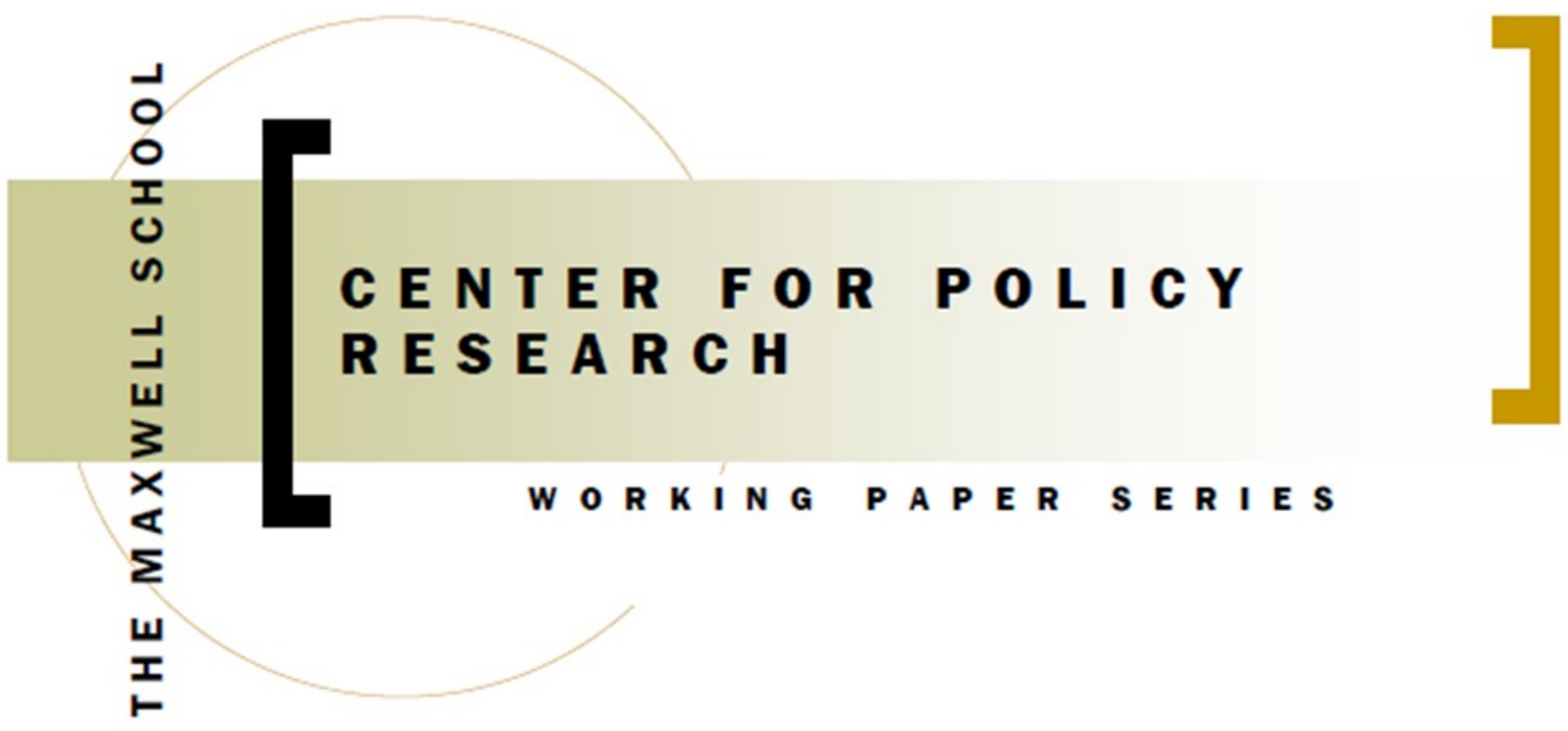

\title{
The Spatial Polish Wage Curve with Gender Effects: Evidence from the Polish Labor Survey
}

Badi H. Baltagi and Bartlomiej Rokicki

\section{ISSN: $1525-3066$}

426 Eggers Hall

Syracuse University

Syracuse, NY 13244-1020

(315) 443-3114 / email: ctrpo|@syr.edu 


\section{CENTER FOR POLICY RESEARCH -Summer 2014}

\section{Leonard M. Lopoo, Director \\ Associate Professor of Public Administration and International Affairs (PAIA)}

\section{Associate Directors}

Margaret Austin

Associate Director

Budget and Administration

John Yinger

Trustee Professor of Economics and PAIA

Associate Director, Metropolitan Studies Program

\section{SENIOR RESEARCH ASSOCIATES}

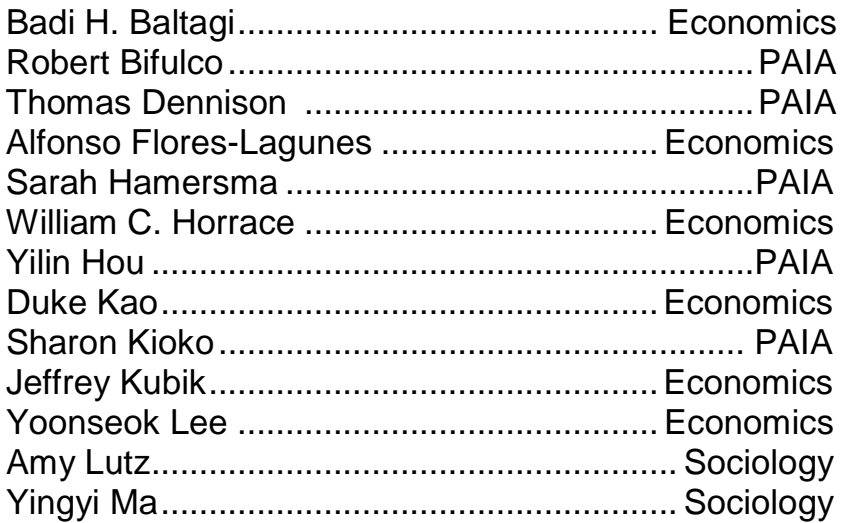

Jerry Miner

Cynthia Morrow

Jan Ondrich.

John Palmer

David Popp

Stuart Rosenthal

Ross Rubenstein

Rebecca Schewe

Amy Ellen Schwartz

Perry Singleton.

Abbey Steele.

Michael Wasylenko....

Peter Wilcoxen.
Economics PAIA

Economics

PAIA

PAIA

Economics PAIA

Sociology

PAIA/Economics

Economics

PAIA

Economics

PAIA

\section{GRADUATE ASSOCIATES}

Emily Cardon

Hannah Dalager

Maidel De La Cruz.

Carlos Diaz.

Vantiel Elizabeth Duncan

Alex Falevich

Lincoln Groves

Ruby Jennings

Yusun Kim

Bridget Lenkiewicz

Michelle Lofton

Roberto Martinez
PAIA Qing Miao

PAIA Nuno Abreu Faro E Mota

PAIA Judson Murchie

Economics

PAIA

Economics

PAIA

PAIA

PAIA

PAIA

PAIA

PAIA
Sun Jung Oh

Brian Ohl

Laura Rodriquez-Ortiz

Timothy Smilnak

Kelly Stevens....

Rebecca Wang

Pengju Zhang

Xirui Zhang
PAIA

Economics PAIA

Social Science PAIA

PAIA

PAIA

PAIA

Sociology

Economics

Economics

\section{STAFF}

Kelly Bogart.

Karen Cimilluca.

Kathleen Nasto
..Administrative Specialist Office Coordinator Administrative Assistant
Candi Patterson. Computer Consultant Mary Santy.... Katrina Wingle
Administrative Assistant Administrative Assistant 


\section{Abstract}

This paper reconsiders the Polish wage curve using individual data from the Polish Labor Force Survey (LFS) at the 16 NUTS2 level allowing for spatial spillovers between regions. In addition it estimates the total and gender-specific regional unemployment rate elasticities on individual wages. The paper finds significant spatial unemployment spillovers across Polish regions. In addition, it finds that the results for the Polish wage curve are sensitive to genderspecific regional unemployment rates. This is especially true for women.

JEL No. C26; J30; J60

Keywords: Wage Curve; Fixed Effects; Spatial Spillovers; Regional Labor Markets

Badi H. Baltagi-Corresponding Author. Syracuse University, Center for Policy Research and Department of Economics, 426 Eggers Hall, Syracuse, New York 13244-1020. (315) 443-1081; E-mail: bbaltagi@maxwell.syr.edu

Bartlomiej Rokicki-University of Warsaw, Faculty of Economic Sciences; and Regional Economics Applications Laboratory, University of Illinois. E-mail: brokicki@wne.uw.edu.pl 


\section{Introduction}

The negative relationship between individual wages and regional unemployment rates, known as a wage curve, has been investigated in a number of papers since the pioneering studies by Blanchflower and Oswald (1990, 2005). The estimates for the unemployment elasticities vary across countries but lie mostly in the neighborhood of -0.1 (e.g. Blanchflower and Oswald, 2005). While most papers include regional fixed effects to control for unobserved heterogeneity, only few account for spatial spillovers between different regions (see for example, Longhi et al., 2006 and Baltagi et al., 2012). Also, very few papers apply gender specific unemployment rates (see Boushey, 2002; Konyali, 2013).

Controlling for region heterogeneity as well as spatial spillovers are important for these wage curve studies. Ignoring them may cause estimation bias and misleading inference. Longhi et al. (2006) argue that once we assume the wage curve to be the result of local monopsonistic competition, we would expect employers to be aware of the employment opportunities not only in the local labor market but also in surrounding areas. Hence, in the absence of spatial spillovers, the local unemployment elasticity is likely to be overestimated. In their study for 327 NUTS3 regions of Western Germany over the period 1990-1997, Longhi et al. (2006) average wage data to confirm the importance of spatial spillovers. They find that the unemployment elasticity is lower in regions strongly interacting with other locations and higher in the ones that are more isolated. This corroborates earlier results by Buettner (1999) who used the same 327 NUTS3 regions of Western Germany over the period 1987-1994 and showed the existence of spatial contiguity effects in wages and unemployment. Elhorst et al. (2007) estimate the wage curve for 114 Eastern German administrative districts over the period 19931999. They show that the introduction of spatially correlated error terms, in order to correct for region-invariant unobserved differences among time periods, highly influences the estimated unemployment elasticity but only when the time period fixed effects are not included in the specification.

Baltagi et al. (2012) also use individual wage data for the 326 German NUTS3 regions over the period 1980-2004 and find spatial unemployment to be insignificant in a dynamic wage curve. They explain that this result may be due to employees being myopic and not caring about the labor market conditions in surrounding areas. Another explanation is the existence of high migration and commuting costs. The dynamic approach to the German wage curve was also 
used by Pannenberg and Schwarze (2000) who used data for 74 Western German regions over the period 1985-1994. They tried to verify the robustness of their results with respect to spatial correlation of the unemployment rates, but could not properly identify their effects due to multicollinearity problems.

The evidence for other countries is rather scarce. Fingleton and Palombi (2013) examine the wage curve with spatial effects for the 408 local authorities in the UK over the period 19982010. They find that the unemployment rate within commuting distance exerts the most influence on wages, while the local unemployment rate accounts for a small fraction of the total impact. Falk and Leoni (2008) estimate a wage curve using grouped data based on 121 districts in Austria for the year 2001. They find that the elasticity of unemployment becomes statistically insignificant once the spatial correlation is ignored. Finally, Ramos et al. (2014) confirm the importance of spatial spillovers for the wage curve results in the case of the Spanish provinces over the period 2000-2010.

It should be noted that the results based on average unemployment rates can be biased for particular subsamples. Hence, Card (1995) suggests applying subsample specific unemployment rates. Though, due to problems with the data representativeness, for the existing studies the only common specification is based on the gender specific unemployment rates. Boushey (2002) examines individual earnings data for the US Metropolitan Statistical Areas and states over the period 1986-1996. She shows that the unemployment elasticity for subsamples of male and female workers changes significantly once group specific unemployment rate is used instead of the aggregate one. Sanroma and Ramos (2005) apply regional data for Spain at the NUTS3 level for 1991. They find that the unemployment elasticities for men and women are significantly higher when the estimation is based on aggregate unemployment rates as compared to gender specific unemployment rates. Konyali (2013) uses individual data for the 12 NUTS1 regions of Turkey over the period 2007-2009. He finds evidence for the wage curve for men based on gender specific estimation only. In the case of women, the unemployment elasticity is statistically insignificant. It should be emphasized though that none of the above gender specific studies use spatial econometric techniques in order to control for spatial spillovers in the unemployment effects. This paper extends the existing literature on the wage curve in a number of ways. First, to the best of our knowledge, it estimates for the first time spatial spillovers using group specific unemployment rates. Second, it focuses on Poland and verifies the existence of different wage curves for 
difference population groups (young versus old, low skilled versus high skilled, etc.). Here, in accordance with Blanchflower and Oswald (1994a) and Card (1995), it verifies that wages for groups with lower bargaining power are more affected by changes in regional unemployment rates than groups with higher bargaining power. Last but not the least, this is the first paper on the Polish wage curve that includes observations far beyond the EU accession date.

Previous literature on the wage curve for Poland include Blanchflower (2001), Iara and Traistaru (2004), Duffy and Walsh (2000, 2001), Rogut (2007) and Yamaguchi (2008). The first two papers focus on estimating wage curves for a group of transition countries rather than Poland per se. More specifically, Iara and Traistaru (2004) use annual regional labor market data at the NUTS 3 level for Bulgaria, Hungary, Poland and Romania for the period 1992 to 1999. They find that average earnings were negatively and significantly associated with regional unemployment rates in Bulgaria and Poland as suggested by the wage curve literature. For the period 1995-1998, for 49 regions (voivodships) in Poland, they find an unemployment elasticity of -0.07 based on 196 observations. On the other hand, Duffy and Walsh (2000) explore the determinants of average monthly wage levels across the same 49 (voivodships) regions of Poland over the period 1991-96. They find an unemployment elasticity of pay for Poland of - 0.12. In their second paper, Duffy and Walsh (2001) use the Polish Force Survey for the years 1994 to 1996. They exclude females arguing that they are more affected by shortterm supply side considerations than their male counterparts. The total number of males in their panel was 14,203 . They find an estimated unemployment elasticity of pay of -0.11 .

Since the 1999 territorial reform, these 49 voivodhips no longer exist. This is why we use the 16 NUTS2 level regions over the period 1999 - 2010. Therefore, our results can be directly comparable to the ones obtained by Rogut (2007) who also studies the Polish wage curve with the NUTS2 level data over the period 1995-2005 and reports an unemployment elasticity of 0.12. To a lesser extent, our results can be compared with the results obtained by Yamaguchi (2008) who uses the Polish Labor Force Survey data over the period $1995-2002^{1}$ and finds an elasticity of about -0.06 .

Figure 1 gives the unemployment rate across these 16 NUTS2 regions over this period.

\footnotetext{
${ }^{1}$ The latter study includes uniform series for the individuals' region of residence for the periods before and after the Polish administrative reform of 1999.
} 
Insert Figure 1 here

Using average wages across regions and over time to estimate a wage curve has been criticized by Card (1995). Hence, in our study we use individual data from the Polish Labor Force Survey over the period 1999-2010. This rich micro-level data set allows us to control for a large number of individual characteristics affecting individuals' wage responses to variations in regional unemployment rates. The sample used includes 102,924 observations of whom 53,886 are males and 49,038 are females. This data set allows us also to control for region effects and spatial spillovers across these regions.

The remainder of the paper is organized as follows. Section 2 describes the model and the data. Section 3 reports the results of the traditional wage curve estimation over the period 1999-2010. Section 4 reports the results of the spatial wage curve. Section 5 reports results of the spatial wage curve with gender-specific unemployment rates. While Section 6 concludes.

\section{The model and data}

The wage curve is simply an inverse relationship between wages and local unemployment rate observed by Blanchflower and Oswald (1990) in their study of the U.S. and British labor markets. The existence of this wage curve was verified for many countries and was even reported to be an empirical law finding this unemployment elasticity to be around -0.1. (For detailed surveys on the wage curve, see Blanchflower and Oswald, 2005; and Nijkamp and Poot, 2005).

Initial explanations of the wage curve proposed by Blanchflower and Oswald (1994) include a labor contract model, an efficiency wage model and a bargaining model. More recently, the theory of monopsonistic competition in local labor markets emerged as another possible explanation of the wage curve phenomenon.

The efficiency wage approach by Shapiro and Stiglitz (1984) assumes that employers will offer a premium to the workers in order to avoid shirking. This way they minimize costs related to monitoring of workers' productivity. The higher the unemployment rate the higher are the probabilities of losing one's job. Hence, firms will offer lower wage premiums when the unemployment rate is higher. 
In the labor turnover model, see Campbell and Orszag (1998), employers use higher wages as a measure to keep current employees and discourage them to quit. This allows them to minimize costs associated with hiring new workers at the times of tight labor markets.

Finally, contrary to previous approaches, the theory of monopsonistic competition relies on the assumption that the local labor markets should not be considered as 'isolated islands' in the national economy. Here, firms entering a local market face start-up costs linked to the recruitment and training process. At the same time workers are exposed to costs related to job searching, commuting or migration. This results in the inverse relationship between wages and unemployment rate. Still, the unemployment elasticity is likely to depend on the employment opportunities in the surrounding areas (for more details see Longhi et al., 2006).

In this paper we follow the monopsonistic competition approach in order to show how the inclusion of spatial spillovers influences the wage curve estimation results. We do not average the data across regions. Instead, we use the individual data. We do not have the location of each individual. This means that we cannot use the spatial autoregression in the error term model (SAR) nor the spatial lagged dependent variable model (SLDV). These models can be estimated for the regional averages since averaging the survey data on individuals transforms it to a panel data on regions. ${ }^{2}$ Using individual data from the Polish Labor Survey, we include the spatial lagged unemployment rate as an additional explanatory variable in the traditional wage curve estimation. The wage curve is a standard wage equation normally used to estimate the returns to education or the male-female wage gap but with the addition of the local unemployment variable to the set of regressors. In our case, we include also the spatial spillover of the regional unemployment rate:

$$
\log W_{i r t}=\alpha+\beta \log U_{r t}+\chi\left(\sum_{s} G_{r s} \log U_{s t}\right)+X_{i r t}^{\prime} \gamma+\mu_{r}+\lambda_{t}+v_{i r t}
$$

where $W_{\text {irt }}$ is the real hourly wage rate of individual $i$ observed in region $r$ at time $t$. $U_{r t}$ is the unemployment rate in region $r$ at time $t$. $\mu_{r}$ is a region effect, $\lambda_{t}$ is a time effect and $v_{i r t}$ is the remainder error term. $X_{\text {irt }}$ represents control variables which include the characteristics of individual $i$ such as: gender, age, age squared, tenure, tenure squared, education, marital status, occupation, industry, sector, size of the employing firm, duration of the job and city size. The matrix $G$ is a spatial weight matrix which symbolizes the connections between regions $\mathrm{r}$ and $\mathrm{s}$

\footnotetext{
2 Previous studies on the German wage curve find weak or insignificant spillover effects using SAR or SLDV models. For example, Buettner (1999) finds no evidence of spatial correlation in the errors and little impact for the inclusion of the spatial lagged dependent variable on the unemployment elasticity.
} 
with typical element $G_{r s}$ where r,s=1,2,..,R. $G$ is of dimension $R \times R$ with diagonal elements equal to zero and it is row-normalized. The latter means that each row sums to one. For example, the r-th row of a contiguity matrix $\mathrm{G}$ gives a 1 for regions that have a common border with the r-th region, and zero otherwise. The number of neighboring or contiguous regions are tallied and the r-th row of $G$ gets divided by this row total. Later in this study, we check the sensitivity of our results to other spatial weight matrices. Hence, the spatially weighted unemployment regressor $\left(\sum_{s} G_{r s} \log U_{s t}\right)$ allows the unemployment rates of the neighboring regions to influence local wages.

In this paper we use micro-level wage data obtained from the Polish Labor Force Survey (LFS) at the 16 NUTS2 level regions over the period 1999 - 2010. The survey does not gather information on wages of self-employed or paid family workers. After excluding the unemployed, inactive and missing observations, we are left with over 102,924 observations of whom 53,886 are males and 49,038 are females. This rich individual level data set allows us to control for a large set of individual characteristics affecting individuals' wage responses to variations in regional unemployment rates. It enables us also to investigate the existence of a wage curve for various types of workers: male vs. female, young vs. old, skilled vs. unskilled, etc. Additionally we use regional unemployment rates based on the LFS data and ESRI shapefile data for Polish NUTS2 regions. See the Appendix for a detailed description of the data.

\section{Traditional wage curve - empirical results}

Table 1 gives the estimation results for the unemployment elasticity of real wages $\beta$, for different types of workers using Equation (1) but without the spatial spillover term ${ }^{3}$. This is a standard fixed effects (FE) estimator with region and time fixed effects. With all individuals in our sample, the unemployment elasticity of real hourly wages is estimated as -0.056 and is significant at the $1 \%$ level. Robust standard errors are reported for all estimates. We also find that males in Poland are significantly more responsive to local unemployment rates $(-0.078)$ than their female counterparts (-0.038). This is in line with the previous findings by Card (1995) for the United States and Baltagi and Blien (1998) for West Germany.

\footnotetext{
${ }^{3}$ In order to save space, we only report $\beta$. However, the results on the other control variables are available upon request from the authors.
} 
Following the classical paper by Card (1995) we estimate also the wage curve for subsamples with different bargaining power in the labor market. Here, we expect to find higher elasticity of unemployment for younger, less qualified or less experienced workers since their bargaining power is lower than older, more experienced and better educated counterparts. Also, we should expect a higher impact of unemployment rate on wages for temporary, private sector and small and medium firms' employees as compared to their permanent, public sector and big firms' counterparts due to the different institutional arrangements ${ }^{4}$.

We find that younger workers aged (15-29) have a significant unemployment elasticity of (0.078) and this increases to (-0.084) for workers aged (30-44), becoming insignificant for workers above 45 years of age. As Duffy and Walsh (2001) argue much of the work experience gained under communism by older workers may not be rewarded so well in a market economy. 5

This unemployment elasticity also varies depending on the worker's skill level, years of tenure, and whether this worker lives in a city or a village. It is insignificant for public sector workers and for whether the employer is a small or a big firm (with 100 or more employees). Temporary workers' wages are more sensitive than permanent workers' wages with an unemployment elasticity of (-0.087) as compared to (-0.056). In summary, the existence of the Polish wage curve is confirmed for all categories considered except for workers over 45 years of age, public sector employees, micro enterprises and firms with 100 or more employees.

\section{Insert Table 1 here}

Next, we check the sensitivity of these results to using the lagged unemployment rate as an instrument for the current unemployment rate, see Baltagi and Blien (1998). These FE-2SLS estimates are shown in Table 1 right below the corresponding FE estimates. The results for all workers as well as men are about the same, but the elasticity for women becomes insignificant. The results remain significant for middle aged workers aged (30-44) and those who live in a

\footnotetext{
${ }^{4}$ Here, permanent and public sector workers are usually covered under better employment protection schemes. At the same time the employees of big enterprises may be protected by labor unions.

${ }^{5}$ For the period 1994-1996, Duffy and Walsh (2001) argued that "under planning, most individuals stayed in the same job for the duration of their working age and the participation rate was high. Working age and job tenure were perfectly correlated." The transition period started to break down this traditional correlation and those that resisted job changes were in the older age groups.
} 
village, as well as private sector workers, and those with more than 1 and less than 11 years of tenure. Also, those who work for medium sized firms. What is interesting is that temporary workers now have a much larger unemployment elasticity (-0.127) as compared to (-0.050) for permanent workers.

Having found that males in Poland are more sensitive to regional unemployment rates as compared to their female counterparts, we focus on finer groupings for males and females separately. Table 2 shows that young males aged (15-29) have the largest unemployment elasticity (-0.147). Men aged (30-44) have also a large and significant unemployment elasticity (-0.101), while men above 45 years of age are not sensitive to the regional unemployment rate. With FE-2SLS only men aged (30-44) have a significant unemployment elasticity (-0.098). Also, only the medium skilled men have a significant unemployment elasticity (-0.123). Men living in cities with less than $100 \mathrm{k}$ inhabitants and in villages have significant unemployment elasticities (-0.13 and -0.092, respectively). Men with more than 1 and less than 11 years of tenure have a significant unemployment elasticity (-0.095). Men in the private sector $(-0.093)$, men with temporary contracts (-0.108) versus permanent contracts (-0.077) and men working for medium size enterprises (-0.095).

Insert Table 2 here

The results for women differ significantly from the ones obtained for men (see Table 3). First of all, the wage curve is found to be significant only in the case of middle aged women (30-44) and only for the FE estimator (-0.068). Also, for low-skilled women (-0.069 for FE and -0.10 for FE-2SLS), women living in a village (-0.06 for FE) and women with medium level of tenure (-0.079 for FE). Women in the private sector (-0.065 for FE and -0.087 for FE-2SLS), women with permanent contracts (- 0.047 for FE) and women with temporary contracts ( -0.134 for FE2SLS). Also, women working for medium sized firms (-0.067 for FE).

Insert Table 3 here

\section{Spatial wage curve}

Table 4 gives the estimation results for the unemployment elasticity of real wages $\beta$, and the spatial spillover unemployment elasticity $\chi$ for different types of workers using Equation $(1)^{6}$.

\footnotetext{
${ }^{6}$ In order to save space, we only report $\beta$ and $\chi$. However, the results on the other control variables are available upon request from the authors.
} 
This is a standard fixed effects (FE) estimator with region and time fixed effects. The spatial spillover is based on the contiguity, row-standardized weight matrix. With all individuals in our sample, the unemployment elasticity of real hourly wages is estimated at -0.047 while the spatial spillover neighboring regions unemployment elasticity is estimated at -0.11 . Both are significant at the $1 \%$ level. Robust standard errors are reported for all estimates.

Our results indicate that high unemployment rates in own and neighboring regions put a downward pressure on local wages. However, local wages are much more affected by the spatially weighted unemployment rates in the neighboring regions than the local ones. This may mean that either a large share of workers is commuting or that firms adjust their wage policy to the situation in the wider regional labor market. Similar or even stronger results were obtained by Fingleton and Palombi (2013) who looked at Great Britain’s 408 unitary authority and local authority areas (UALADs) over the period 1998-2010. They find that local wages do not respond to unemployment in the immediate area but are strongly determined by unemployment within commuting distance (spillover effects).

We also find that males in Poland are significantly more responsive to local unemployment rates (-0.067) than their female counterparts (-0.031). Again spatial spillovers are of higher magnitudes and statistically significant, (-0.135 for men and -0.086 for women, respectively). Younger workers aged (15-29) have a significant unemployment elasticity of (-0.062) and this increases to (-0.074) for workers aged (30-44), becoming insignificant for workers above 45 years of age. This corroborates the findings of Duffy and Walsh (2001) who argue that the work experience gained under communism by older workers may not be rewarded so well in a market economy.

These unemployment elasticities also vary depending on the worker's skill level, years of tenure, and whether this worker lives in a city or a village. Own region unemployment elasticity is significant in 17 out of 22 cases considered. The insignificant cases include workers above 45 years of age, workers with less than 2 years tenure, public sector workers, and workers whose employer is a small firm (less than 10 employees) or a big firm (with 100 or more employees). We also found large and statistically significant spatial spillover neighboring regional unemployment elasticities in 18 out of 22 cases considered. The insignificant spatial spillover regional unemployment elasticities were for workers with more than 10 years tenure, large cities with more than 100 thousand inhabitants, high skilled workers, and workers above 45 years of 
age. Whenever, this spatial spillover elasticity was significant, it was of a higher order of magnitude in absolute value than the own region employment elasticity.

\author{
Insert Table 4 here
}

Next, we check the sensitivity of these results to applying instrumental variables estimation where the instruments are the lagged unemployment rate and lagged spatial regional unemployment spillover effect. The results are labeled FE-2SLS and are shown in Table 4 right below the corresponding FE estimates. The results for all workers as well as men are about the same, but the own region elasticity for women becomes insignificant. Furthermore, in most cases, the local unemployment elasticity is slightly lower, as compared to the FE estimation, while the spillover elasticity is now slightly higher. This indicates that neighboring unemployment effects may have a lingering effect on local wages. Spatial spillover effects were significant in 18 out of 22 cases considered. Spillover unemployment elasticities were not significant for workers above 45 years of age, workers living in cities over 100k, high skilled or public sector workers.

\title{
4.1 Gender Differences
}

Having found that males in Poland are more sensitive to own and spatial regional unemployment rates as compared to their female counterparts, we focus on finer groupings for males and females separately. Table 5 shows that young males aged (15-29) have a high unemployment elasticity (-0.126) and the largest spatial spillover effect (-0.300). Men aged (3044) have also a large and significant unemployment elasticity (-0.089) and a large spillover effect (-0.161), while men above 45 years of age are not sensitive to the regional unemployment rate. Spatial unemployment spillover is significant in 13 out of 22 cases considered. The highest own region unemployment elasticity is found for men with temporary contracts $(-0.128)$. However, in that case, the spatial spillover is statistically insignificant.

Insert Table 5 here

The FE-2SLS estimates are very similar to the corresponding FE ones. Some notable differences include the lack of significance of spatial spillover in the case of medium skilled workers, workers living in cities, and workers with the lowest tenure. 
The results for females differ significantly from the ones obtained for males (see Table 6). The overall unemployment elasticity is (-0.031) as compared to (-0.067) for males. The female's wage curve is found to be significant only in the case of middle aged women (-0.062); lowskilled women (-0.061); women with medium level of tenure (-0.073); women in the private sector (-0.050), women with permanent contracts (-0.045) and women working for medium sized firms (-0.061). The spatial unemployment spillover is significant in 9 out of 20 cases considered. It is not significant for example for older and higher skilled women, women living in cities. Also, women with more than 10 years of tenure, women working in the public sector, and women working in medium and big size firms.

\section{Insert Table 6 here}

Again, the FE-2SLS estimates are very similar to the corresponding FE ones. However, unlike the case of men, the spatial spillover for women becomes statistically significant, as compared to the FE estimates. This applies to women aged 30-44, women with permanent contracts, or employed by medium and big enterprises.

\subsection{Sensitivity to Different Spatial Weight Matrices}

Next, we check the sensitivity of our results to alternative spatial weight matrices used to capture the spillover effects of regional unemployment. So far in Tables 4-6, we have used the contiguity weight matrix. This basically indicates that regions $r$ and $s$ are neighbors depending on whether they are geographically contiguous. In this section we employ two other weight matrices based on the inverse (Euclidean) distance between regions $r$ and $\mathrm{s}$. We also used the inverse square distance between regions $\mathrm{r}$ and $\mathrm{s}$. All spatial weight matrices were row normalized. ${ }^{7}$

It should be noted that the role played by the spatial weight matrix has long been a controversial aspect of spatial regression methods. In accordance to Le Sage (2014) "much of the controversy stems from the mistaken belief that minor changes in specification of the weight matrix produce major changes in spatial regression model estimates and inferences”. Our robustness check confirms the above finding since the regression results do not change significantly.

\footnotetext{
${ }^{7}$ We do not have data on commuting, so we are limited in the type of spatial weight matrices we can use.
} 
Comparing the results for the inverse distance spatial weight matrix (reported in Table 7) with those for the spatial contiguity weight matrix (reported in Table 4), we see an increase in the local unemployment elasticities, from -0.047 to -0.058 for all workers, and from -0.067 to 0.083 for men, to mention a couple of examples. Moreover, the spatial spillover unemployment elasticities become statistically insignificant for the basic FE specifications. However, for the FE-2SLS regressions, we find significant lagged spatial spillover effects while in most of the cases the local unemployment rate elasticity becomes statistically insignificant.

\section{Insert Table 7 here}

The results for the inverse square distance spatial weight matrix (reported in Table 8) are almost identical to the ones obtained for the contiguity spatial weight matrix (reported in Table 4). In summary, we conclude that the choice of the weight matrix may affect the magnitude but not the significance or sign of the unemployment elasticities.

Insert Table 8 here

Elhorst (2010) claims that "if a spatial interaction model is estimated based on S different spatial weight matrices and the log-likelihood function value of every model is estimated, one may select the spatial weights matrix exhibiting the highest log-likelihood function value”. In our case the highest value of the log-likelihood function was found for the contiguous matrix specification.

\section{Spatial wage curve with gender-specific unemployment rates}

In this section, we re-estimate the Polish wage curve with spatial spillovers basing it on genderspecific regional unemployment rates rather than the total regional unemployment rates. We have already seen a major difference in the estimated elasticities across gender when using total regional unemployment rates. Here, we are interested in how the female unemployment rate affects the wages of females, and similarly for males. Although this approach was applied in a few studies, none of them took into account spatial spillovers.

Most wage curve studies use the total regional unemployment rate as a measure of job competition perhaps under the assumption that both men and women are competing for the 
same jobs (e.g. Longhi, 2012) ${ }^{8}$. However, this assumption may not be reasonable for Poland, where the transition from the communist system made the gender specific labor market regulations work against women (e.g. Siemieńska, 1996). Let us elaborate on that.

First, the share of men and women vary within different occupation categories, different sectors and different economic activities. According to the Polish Statistical Office (2012), in 2011, the share of women exceeded $60 \%$ for the following occupation categories: specialists, office staff, personal services staff and dealers. On the other hand, this share did not reach $15 \%$ for categories such as industrial workers and craftsmen or operators and assemblers of machinery and equipment. $66.3 \%$ of women worked for the private sector as compared to $81.3 \%$ for men. The share of women was less than $10 \%$ in construction and over $80 \%$ in health care and social assistance.

Second, empirical studies on the Polish labor market show that the employers have defined gender preferences at the time of hiring for a particular post. Not surprisingly men are preferred for jobs requiring physical attributes, women for jobs requiring better social skills (sellers, services or office workers). For example, in 2012, almost $70 \%$ of the employers declared a given gender as a requirement towards candidates to professional posts (e.g. Polish Agency for Enterprise Development, 2013). The remarkable exception relates to the occupation category of professionals where gender mattered for only $20 \%$ of the employers. Still, the data indicates that there are certain preferences even within the above category; e.g. men were usually sought to work as IT professionals, while women were preferred as teachers or business and administration professionals.

Finally, men and women have different preferences at the time of job seeking. For example, women are far less likely to change their employer (see Polish Agency for Enterprise Development, 2013). Also, women, almost exclusively, use the existing mechanisms that allow the worker to match the economic activity with household tasks (e.g. part-time work, flexible working hours, etc.). Even though many of these mechanisms applied to both genders (e.g. Kotowska et al., 2007). As a result, the unemployment rates for men and women may be significantly different in particular regions. Furthermore, their evolution may also differ, since it is linked to the evolution of particular industries within a given region.

\footnotetext{
${ }^{8}$ Some exceptions include papers by Boushey (2002) for the US, Konyali (2013) for Turkey, and Sanroma and Ramos (2005) for Spain.
} 
Figure 2 shows the gender-specific unemployment rate for 3 different Polish regions. It shows the different levels of unemployment rates (usually higher for women) and the evolution of these unemployment rates. Note that in 1998, the unemployment rate for men in Zachodniopomorskie was more than 5\% points lower than that for women. In contrast, in 2010, the unemployment rate for women was only $1.6 \%$ points lower than the unemployment rate for men. Hence, we believe that it is useful to look at gender-specific unemployment rate elasticities in wage curve estimation results.

\section{Insert Figure 2 here}

The gender-specific wage curve basically replaces the unemployment rate in region $r$ at time $t$ $\left(U_{r t}\right)$ in (1) with the gender specific unemployment rate $\left(U_{r g t}\right)$ in region $r$, for gender $g$ at time $t$. Table 9 gives the estimation results for the men subsample using the men's regional unemployment rate, based on the contiguity spatial weight matrix. This can be compared to the results for men, based on the total regional unemployment rate in Table 5. The estimated elasticities are slightly lower for all men going from (-0.067) in Table 5 to (-0.062) in Table 9. This reduction is more drastic for young men aged 15-29, where this elasticity estimate drops from (-0.126) to (-0.108). The spatial spillover unemployment elasticity is also much lower dropping from (-0.135) for all men in Table 5 to (-0.109) in Table 9. Once again, this reduction is more drastic for young men aged 15-29, where this elasticity estimate drops from (-0.300) in Table 5 to $(-0.208)$ in Table 9.

\section{Insert Table 9 here}

The FE-2SLS estimates for men in Table 9 do not differ substantially from the corresponding FE ones. Some notable differences include the lack of significance of spatial spillover in the case of high skilled workers, workers living in big cities, and workers with the lowest tenure.

Table 10 gives the estimation results for the female subsample using the women's regional unemployment rate, based on the contiguity spatial weight matrix. This can be compared to the results for females, based on the total regional unemployment rate in Table 6. Note that for all female workers, the own region unemployment elasticity is now statistically insignificant. However, this female own region unemployment elasticity remains statistically significant in the case of middle aged women, low skilled women, women with tenure between 1 and 10 years, women working for the private sector, with permanent contract and women in medium 
sized firms. These significant unemployment elasticities are slightly lower in Table 10 compared to those in Table 6. In contrast, there is an increase in the magnitude of the spatial spillover unemployment elasticity for females in almost all specifications. For example, this elasticity increases from -0.086 for all female workers in Table 6 to -0.10 in Table 10 . For young women aged 15-29, this elasticity increases from -0.136 in Table 6 to -0.160 in Table 10. One exception is women with less than 2 years of tenure where this elasticity drops from 0.241 in Table 6 to -0.224 in Table 10. The FE-2SLS estimates in Table 10 are in line with the FE ones.

Insert Table 10 here

The above results confirm important differences between the genders in the Polish labor market. They also show that the Polish wage curve results are sensitive to the application of genderspecific unemployment rates rather than the total unemployment rate. ${ }^{9}$ In this sense they are in line with the ones found in other papers applying gender-specific unemployment rate for the US, Turkey and Spain, (see Boushey, 2002; Konyali, 2013; and Sanroma and Ramos, 2005). Unlike these papers, ours account for spatial spillovers.

\section{Conclusion}

This paper reconsiders the Polish wage curve using individual data from the Polish Labor Force Survey (LFS) at the 16 NUTS2 level allowing for spatial spillovers between these regions and applying gender specific unemployment rates. Our estimates confirm the existence of the wage curve in Poland with an overall unemployment elasticity around -0.06. We also find that the unemployment elasticity of male wages in Poland over the period 1999-2010 is double that for women. These results are in line with the findings by Card (1995) for the United States and Baltagi and Blien (1998) for West Germany. Moreover, if the lagged unemployment rate is used as an instrument for current unemployment rate, we find that the unemployment elasticity increases substantially for less experienced workers as well as temporary workers.

Accounting for spatial spillovers, we find that the own region unemployment elasticity of all workers decreases from -0.06 to -0.05 . But, the spatial spillover unemployment elasticity is large -0.11 and statistically significant. The spatial wage curve results are sensitive in

\footnotetext{
${ }^{9}$ Note that Longhi (2012) applies theoretically-based measures of job competition for the UK, and finds a much larger impact on wages for women than on wages for men.
} 
magnitude but not in sign and significance to the different spatial weight matrices used to account for the spatial spillovers.

This paper also finds that the Polish wage curve results are sensitive to using gender-specific regional unemployment rates. Our results show that the own gender specific unemployment elasticity and the gender specific spatial spillover unemployment effects are smaller in magnitude for the men subsample. In contrast, our results show that gender specific own unemployment elasticity becomes statistically insignificant in the case of women. But, the spatial spillover female regional unemployment elasticity remains significant.

\section{References}

Baltagi, B.H., Blien, U., 1998. The German Wage Curve: Evidence from the IAB Employment Sample. Economics Letters 61, 135-142.

Baltagi, B.H., Blien, U., Wolf, K. 2012. A Dynamic Spatial Panel Data Approach to the German Wage Curve. Economic Modelling 29(1), 12-21.

Blanchflower, D.G., 2001. Unemployment, Well-Being, and Wage Curves in Eastern and Central Europe. Journal of the Japanese and International Economies 15, 364-402.

Blanchflower, D.G., Oswald, A.J., 1990. The Wage Curve. Scandinavian Journal of Economics 92, 215-235.

Blanchflower, D. G., Oswald, A. J., 1994. The Wage Curve. Cambridge (Mass.), London: MIT Press.

Blanchflower, D.G., Oswald, A.J., 1995. An Introduction to the Wage Curve. Journal of Economic Perspectives 9, 153-167.

Blanchflower, D.G., Oswald, A.J., 2000. International Wage Curves. In Differences and Changes in Wage Structures, edited by Richard Freeman and Larry Katz, University of Chicago Press and NBER.

Blanchflower, D.G., Oswald, A.J., 2005. The Wage Curve Reloaded. NBER Working Paper Series, Vol. w11338. Available at SSRN: http://ssrn.com/abstract=723307.

Boushey, H., 2002. Reworking the Wage Curve: Exploring the Consistency of the Model Across Time, Space and Demographic Group. Review of Political Economy 14(3), 293-311.

Buettner, T. 1999. The Effect of Unemployment, Aggregate Wages, and Spatial Contiguity on Local Wages: An Investigation with German Region Level Data. Papers in Regional Science 78, 47-68.

Campbell, C., Orszag, J.M., 1998. A Model of the Wage Curve. Economics Letters 59, 119125. 
Card, D., 1995. The Wage Curve: A Review. Journal of Economic Literature 33, 285-299.

Duffy, F., Walsh, P. P., 2000. A Regional Analysis of Wage Determination in Poland, LICOS Discussion Paper, No. 87.

Duffy, F., Walsh, P., 2001. Individual Pay and Outside Options: Evidence from the Polish Labour Force Survey. IZA Discussion Paper 295.

Elhorst, J. P., 2010. Applied Spatial Econometrics: Raising the Bar. Spatial Economic Analysis 5(1), 9-28.

Elhorst, J. P., Blien, U., Wolf, K., 2007. New Evidence on the Wage Curve: A Spatial Panel Approach. International Regional Science Review 30(2), 173-191.

Falk, M., Leoni, T., 2008. Further Evidence on the Wage Curve for Austria. WIFO.

Fingleton, B., Palombi, S., 2013. The Wage Curve Reconsidered: Is It Truly an 'Empirical Law of Economics'? Région et Développement 38, 49-92.

Iara, A., Traistaru, I., 2004. How Flexible are Wages in EU Accession Countries? Labour Economics 11, 431-450.

Konyali, G., 2012. Wage Curve Evidence from Turkey’s 2007-2009 Income and Living Conditions Survey. Investigaciones Regionales 24, 199-210.

Kotowska, I., Sztanderska, U., Wóycicka, I. (eds.). Professional and Educational Activity versus Familiar Duties in Poland. Scholar, Warsaw.

LeSage, J. P., 2014. What Regional Scientists Need to Know About Spatial Econometrics. Working paper.

Longhi, S. 2012. Job Competition and the Wage Curve. Regional Studies 46(5), 611-620.

Longhi, S., Nijkamp, P., Poot, J., 2006. Spatial Heterogeneity and the Wage Curve Revisited. Journal of Regional Science 46(4), 707-731.

Nijkamp, P., Poot, J., 2005. The Last Word on the Wage Curve? Journal of Economic Surveys 19(3), 421-450.

Pannenberg, M., Schwarze, J., 2000. Wage Dynamics and Unemployment in Germany: Evidence from Regional Panel Data. Labour 14(4), 645-655.

Polish Agency for Enterprise Development, 2013. Youth or Experience? Human Capital in Poland. The report concluding the 3rd round of the BKL Study in 2012. Warsaw.

Polish Statistical Office, 2012. Men and Women on the Labour Market. Warsaw. 
Ramos, R., Nicodemo, C., Sanroma, E., 2014. A Spatial Panel Wage Curve for Spain. Forthcoming in Letters in Spatial and Resource Sciences.

Rogut, A., 2007. The Wage Curve in Poland in 1995-2005. Bank i Kredyt 38(4), 18-38.

Sanroma, E., Ramos, R., 2005. Further Evidence on Disaggregated Wage Curves: The Case of Spain. Australian Journal of Labour Economics 8(3), 227-243.

Shapiro, C., Stiglitz, J.E., 1984. Equilibrium Unemployment as a Worker Discipline Device. American Economic Review 74, 433-444.

Siemieńska, R., 1996. Gendered Perceptions: Women in the Labour Market in Poland. Women's History Review 5(4), 553-566.

Yamaguchi, S., 2008. Wage Flexibility in Turbulent Times: A Practitioner's Guide, with an Application to Poland. Eastern European Economics 46(2), 88-114. 


\section{Data Appendix}

The data set used in the present study is based on the fourth quarter of the Polish Labor Force Survey (LFS) for the period 1999-2010 ${ }^{10}$. The survey does not gather information on wages of self-employed or paid family workers. After excluding the unemployed, inactive and missing observations, we are left with over 102,924 observations.

The data from the Polish Labor Force Survey provides information on the region (at the NUTS2 level) where the employee is located and the size of the city where he or she lives. Furthermore, the Survey gives data on personal characteristics, employment spell and employer. In this study we use individual net hourly wage deflated by the national consumer price index. We also apply the unemployment rate calculated on the basis of the LFS data, taken from the Polish Central Statistical Office for the population aged $15+$.

The control variables used in the regressions are the following:

- $\quad$ Age of the individual

- $\quad$ Gender. Male $=0$ and female $=1$.

- $\quad$ Marital status. This variable includes 4 categories: Married, Single, Widow, Divorced.

- Education. This variable includes 7 different categories: higher (including second stage of tertiary education $)=7$, post-secondary $=6$, secondary vocational $=5$, general secondary $=$ 4 , vocational $=3$, primary and lower secondary $=2$, incomplete primary and no education $=1$.

- $\quad$ Region. We distinguish among 16 Polish NUTS2 regions.

- City size. This variable includes 8 categories: city with population over 100 thousand $=7$, $50-99.9$ thousand $=6,20-49.9$ thousand $=5,10-19.9$ thousand $=4,5-9.9$ thousand $=3,2-4.9$ thousand $=2$, less than 2 thousand $=1$, village $=0$.

- The individual's years of tenure at the firm.

- $\quad$ Type of work. Permanent contract $=0$, temporary contract $=1$.

- Occupation. This variable includes 9 categories: representatives of the public authorities, senior officials and managers, specialists, technicians and other medium staff, office staff, personal services staff and dealers, farmers, gardeners, foresters and fishermen, industrial

\footnotetext{
${ }^{10}$ The survey is being conducted quarterly, so there are 4 data sets each year.
} 
workers and craftsmen, operators and assemblers of machinery and equipment, employed in elementary occupations.

- Industry classification. This variable defines the specific industry to which the employing establishment belongs, in accordance to the NACE rev. 1.1 classification. These include 15 categories such as: primary sector, mining and quarrying, manufacturing, electricity, gas and water supply, construction, trade and repair, hotels and restaurants, transport, storage and communication, financial intermediation, real estate, renting and business activities, public administration, education, health care and social work, other community, social and personal service activities, households.

- Firm size. This variable includes 5 categories: up to 10 employees $=1,11-19$ employees $=$ 2, 20-49 employees $=3,50-100$ employees $=4$, over 100 employees $=5$.

- $\quad$ Sector. Public $=0$, private $=1$.

\section{Summary statistics}

$\begin{array}{llllrr}\text { Variable } & \text { Obs } & \text { Mean } & \text { Std. Dev. } & \text { Min } & \text { Max } \\ \text { region } & 102924 & 16.87016 & 9.333652 & 2 & 32 \\ \text { citysize } & 102924 & 3.558908 & 2.932758 & 0 & 7 \\ \text { year } & 102924 & 2004.214 & 3.471274 & 1999 & 2010 \\ \text { gender } & 102924 & 0.476449 & 0.499448 & 0 & 1 \\ \text { age } & 102924 & 39.11169 & 10.73141 & 15 & 74 \\ \text { marital status } & 102924 & 0.369302 & 0.717564 & 0 & 3 \\ \text { education } & 102924 & 4.433699 & 1.625184 & 1 & 7 \\ \text { sector } & 102924 & 0.579185 & 0.493692 & 0 & 1 \\ \text { section } & 102924 & 10.08004 & 4.008244 & 2 & 18 \\ \text { firmsize } & 102924 & 3.360344 & 1.495728 & 1 & 5 \\ \text { typeofwork } & 102924 & 0.192414 & 0.394198 & 0 & 1 \\ \text { tenure } & 102924 & 9.428034 & 9.439289 & 0 & 53 \\ \text { unemployment rate } & 102924 & 14.93793 & 5.264154 & 5.5 & 26.3 \\ \text { occupation } & 102924 & 3.715013 & 2.512657 & 0 & 8 \\ \text { hourly wage } & 102924 & 6.402670 & 3.573979 & 2.5 & 37.5\end{array}$


Figure 1: Regional Unemployment in Poland, 1998-2010

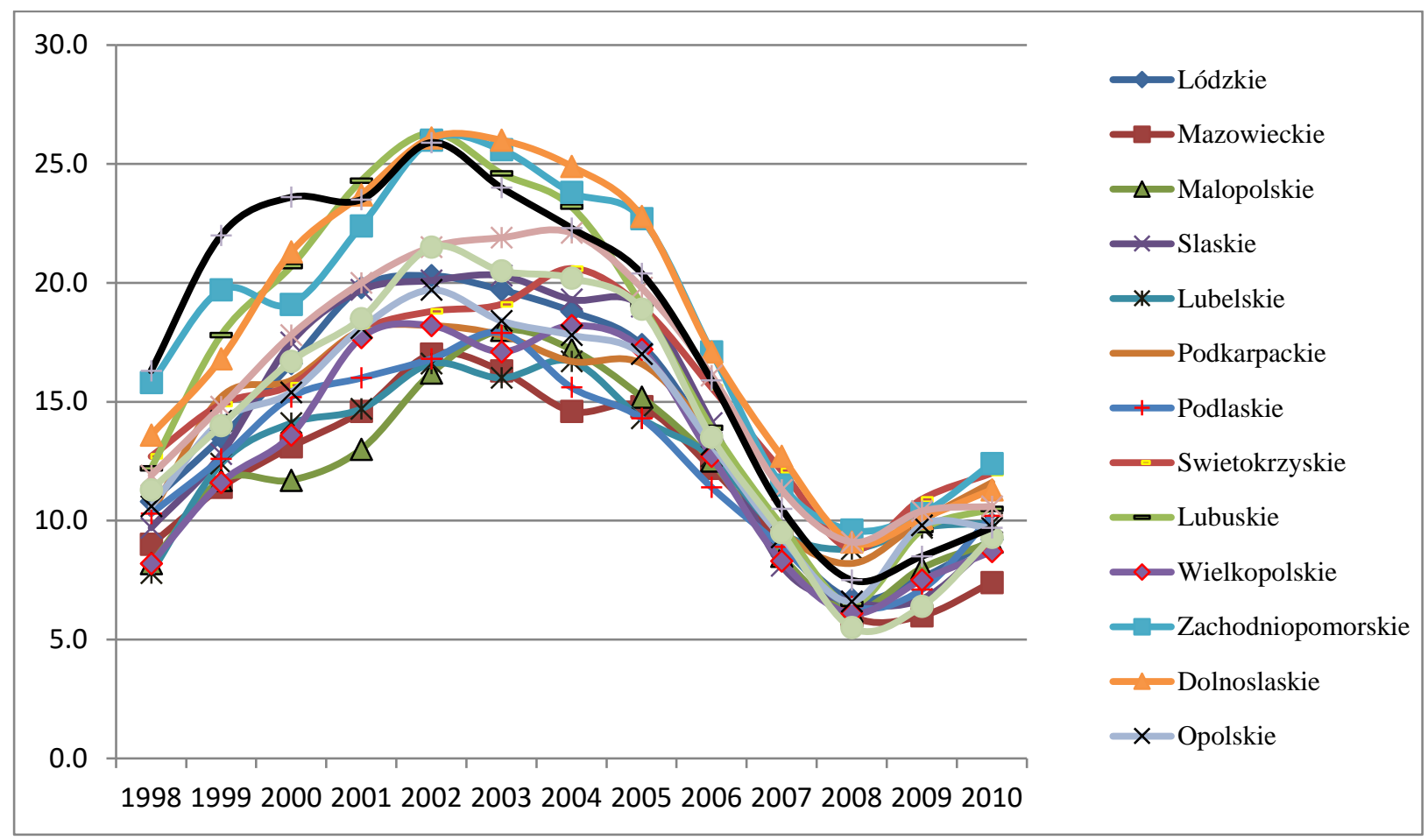

Source: This is based on data from the Polish Central Statistical Office 
Figure 2: Regional Gender-Spcific Unemployment Rates in Poland, 1998-2010 (3 example regions)

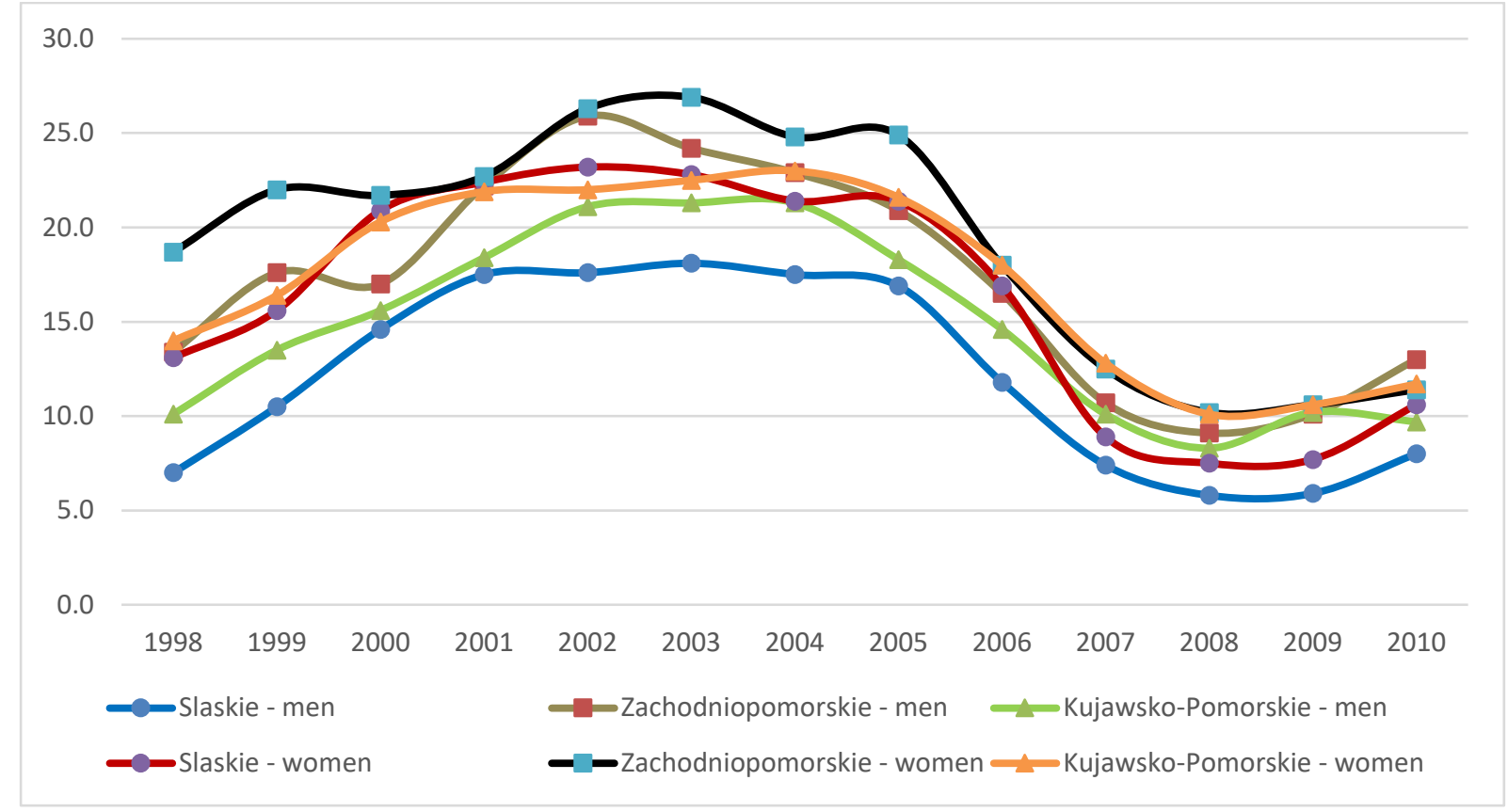

Source: This is based on data from the Polish Central Statistical Office 
Table 1 The Polish unemployment elasticity of real hourly wages by worker type

\begin{tabular}{|c|c|c|c|c|c|c|c|c|c|c|c|c|}
\hline & All workers & Men & Women & $\begin{array}{c}\text { Age } \\
15-29\end{array}$ & $\begin{array}{c}\text { Age } \\
30-44\end{array}$ & $\begin{array}{c}45 \text { and } \\
\text { older }\end{array}$ & $\begin{array}{l}\text { Low } \\
\text { skill }\end{array}$ & $\begin{array}{l}\text { Medium } \\
\text { skill }\end{array}$ & $\begin{array}{l}\text { High } \\
\text { skill }\end{array}$ & Village & $\begin{array}{l}\text { City up to } \\
100 \mathrm{k}\end{array}$ & $\begin{array}{c}\text { City over } \\
100 \mathrm{k}\end{array}$ \\
\hline Fixed effects & $\begin{array}{c}-0.056 * * * \\
(0.012)\end{array}$ & $\begin{array}{c}-0.078 * * * \\
(0.017)\end{array}$ & $\begin{array}{c}-0.038 * * \\
(0.016)\end{array}$ & $\begin{array}{c}-0.078 * * * \\
(0.024)\end{array}$ & $\begin{array}{c}-0.084 * * * \\
(0.018)\end{array}$ & $\begin{array}{l}-0.006 \\
(0.019)\end{array}$ & $\begin{array}{c}-0.052 * * * \\
(0.016)\end{array}$ & $\begin{array}{c}-0.049 * * * \\
(0.018)\end{array}$ & $\begin{array}{c}-0.062 * * \\
(0.031)\end{array}$ & $\begin{array}{c}-0.074 * * * \\
(0.018)\end{array}$ & $\begin{array}{c}-0.056 * * * \\
(0.019)\end{array}$ & $\begin{array}{c}-0.052 * * \\
(0.026)\end{array}$ \\
\hline R-squared & 0.51 & 0.46 & 0.56 & 0.42 & 0.52 & 0.52 & 0.36 & 0.38 & 0.36 & 0.49 & 0.51 & 0.48 \\
\hline FE- 2SLS & $\begin{array}{c}-0.057 * * * \\
(0.019)\end{array}$ & $\begin{array}{c}-0.078 * * * \\
(0.028)\end{array}$ & $\begin{array}{l}-0.041 \\
(0.027)\end{array}$ & $\begin{array}{l}-0.057 \\
(0.039)\end{array}$ & $\begin{array}{c}-0.082 * * * \\
(0.031)\end{array}$ & $\begin{array}{l}-0.029 \\
(0.032)\end{array}$ & $\begin{array}{c}-0.042 \\
(0.027)\end{array}$ & $\begin{array}{c}-0.058 * \\
(0.030)\end{array}$ & $\begin{array}{l}-0.057 \\
(0.052)\end{array}$ & $\begin{array}{c}-0.087 * * * \\
(0.028)\end{array}$ & $\begin{array}{c}-0.061 * \\
(0.032)\end{array}$ & $\begin{array}{l}-0.020 \\
(0.048)\end{array}$ \\
\hline -squared & 0.51 & 0.46 & 0.56 & 0.42 & 0.52 & 0.52 & 0.36 & 0.38 & 0.36 & 0.49 & 0.51 & 0.48 \\
\hline Observations & 102,924 & 53,886 & 49,038 & 24,460 & 42,635 & 35,829 & 42,815 & 40,482 & 19,627 & 36,997 & 38,879 & 27,048 \\
\hline
\end{tabular}

\begin{tabular}{|c|c|c|c|c|c|c|c|c|c|c|}
\hline & Tenure<2 & Tenure >1\&<11 & Tenure $>10$ & $\begin{array}{l}\text { Public } \\
\text { sector }\end{array}$ & $\begin{array}{l}\text { Private } \\
\text { sector }\end{array}$ & $\begin{array}{l}\text { Permanent } \\
\text { work }\end{array}$ & $\begin{array}{l}\text { Temporary } \\
\text { work }\end{array}$ & Small firm & $\begin{array}{l}\text { Medium } \\
\text { firm }\end{array}$ & Big firm \\
\hline Fixed effects & $\begin{array}{c}-0.049 * * \\
(0.024)\end{array}$ & $\begin{array}{c}-0.065^{* * *} \\
(0.018)\end{array}$ & $\begin{array}{c}-0.047 * * \\
(0.019)\end{array}$ & $\begin{array}{c}-0.021 \\
(0.018)\end{array}$ & $\begin{array}{c}-0.074 * * * \\
(0.015)\end{array}$ & $\begin{array}{c}-0.056^{* * *} \\
(0.013)\end{array}$ & $\begin{array}{c}-0.087 * * * \\
(0.027)\end{array}$ & $\begin{array}{c}-0.024 \\
(0.028)\end{array}$ & $\begin{array}{c}-0.086^{* * *} \\
(0.017)\end{array}$ & $\begin{array}{c}-0.022 \\
(0.020)\end{array}$ \\
\hline R-squared & 0.41 & 0.49 & 0.52 & 0.54 & 0.44 & 0.51 & 0.38 & 0.39 & 0.53 & 0.48 \\
\hline FE- 2SLS & $\begin{array}{l}-0.075^{*} \\
(0.040)\end{array}$ & $\begin{array}{c}-0.071^{* *} \\
(0.031)\end{array}$ & $\begin{array}{c}-0.025 \\
(0.032)\end{array}$ & $\begin{array}{c}-0.005 \\
(0.031)\end{array}$ & $\begin{array}{c}-0.085^{* * *} \\
(0.025)\end{array}$ & $\begin{array}{c}-0.050^{* *} \\
(0.022)\end{array}$ & $\begin{array}{c}-0.127 * * * \\
(0.045)\end{array}$ & $\begin{array}{c}-0.044 \\
(0.045)\end{array}$ & $\begin{array}{c}-0.071^{* * *} \\
(0.027)\end{array}$ & $\begin{array}{c}-0.034 \\
(0.035)\end{array}$ \\
\hline R-squared & 0.41 & 0.49 & 0.52 & 0.54 & 0.44 & 0.51 & 0.38 & 0.39 & 0.53 & 0.48 \\
\hline Observations & 23,658 & 42,916 & 36,350 & 43,312 & 59,612 & 83,120 & 19,804 & 17,810 & 49,434 & 35,680 \\
\hline
\end{tabular}

Notes:

a) Robust standard errors in parentheses. *, ** and *** represent significance at $10 \%, 5 \%$ and $1 \%$, respectively.

b) Low skill workers refer to individuals with vocational, lower secondary, primary or no education. Medium skill workers refer to individuals with post-secondary (non-tertiary), vocational secondary or secondary education. High skill workers refer to tertiary and higher education attainment.

c) Small firms refer to enterprises with up to 10 employees. Medium firms refer to enterprises with more than 10 and up to 100 employees. Big firms refer to enterprises with more than 100 employees.

d) In FE-2SLS specification, the logarithm of unemployment rate by region in the previous year has been used as an instrument for the logarithm of unemployment rate by region at time t. 
Table 2 The Polish men unemployment elasticity of real hourly wages by worker type

\begin{tabular}{|c|c|c|c|c|c|c|c|c|c|c|c|c|}
\hline & $\begin{array}{c}\text { All } \\
\text { workers }\end{array}$ & $\begin{array}{c}\text { Age } \\
15-29\end{array}$ & \multicolumn{2}{|c|}{$\begin{array}{c}\text { Age } \\
30-44\end{array}$} & $\begin{array}{c}45 \text { and } \\
\text { older }\end{array}$ & $\begin{array}{l}\text { Lo } \\
\text { ski }\end{array}$ & $\begin{array}{l}\text { Medium } \\
\text { skill }\end{array}$ & $\begin{array}{l}\text { High } \\
\text { skill }\end{array}$ & Village & $\begin{array}{l}\text { City up to } \\
100 \mathrm{k}\end{array}$ & $\begin{array}{l}\text { City over } \\
100 \mathrm{k}\end{array}$ & \\
\hline Fixed effects & $\begin{array}{c}-0.078 * * * \\
(0.017)\end{array}$ & $\begin{array}{c}-0.147 * * * \\
(0.032)\end{array}$ & \multicolumn{2}{|c|}{$\begin{array}{c}-0.101^{* * *} \\
(0.026)\end{array}$} & $\begin{array}{l}-0.005 \\
(0.028)\end{array}$ & $\begin{array}{c}-0.047 * * \\
(0.021)\end{array}$ & $\begin{array}{c}-0.096 * * * \\
(0.029)\end{array}$ & $\begin{array}{c}-0.111^{* *} \\
(0.055)\end{array}$ & $\begin{array}{c}-0.084 * * * \\
(0.024)\end{array}$ & $\begin{array}{c}-0.098 * * * \\
(0.028)\end{array}$ & $\begin{array}{l}-0.062 \\
(0.040)\end{array}$ & \\
\hline R-squared & 0.39 & 0.46 & \multicolumn{2}{|c|}{0.48} & 0.33 & 0.36 & 0.34 & 0.41 & 0.46 & 0.46 & 0.46 & \\
\hline FE- 2SLS & $\begin{array}{c}-0.078 * * * \\
(0.028)\end{array}$ & $\begin{array}{l}-0.102 * \\
(0.052)\end{array}$ & \multicolumn{2}{|c|}{$\begin{array}{c}-0.098^{* *} \\
(0.044)\end{array}$} & $\begin{array}{l}-0.024 \\
(0.047)\end{array}$ & $\begin{array}{l}-0.017 \\
(0.034)\end{array}$ & $\begin{array}{c}-0.123 * * \\
(0.048)\end{array}$ & $\begin{array}{l}-0.112 \\
(0.092)\end{array}$ & $\begin{array}{c}-0.092 * * \\
(0.038)\end{array}$ & $\begin{array}{c}-0.130 * * * \\
(0.046)\end{array}$ & $\begin{array}{c}0.032 \\
(0.074)\end{array}$ & \\
\hline $\begin{array}{l}\text { R-squared } \\
\text { Observations }\end{array}$ & $\begin{array}{c}0.39 \\
13,931\end{array}$ & $\begin{array}{c}0.46 \\
21,639\end{array}$ & \multicolumn{2}{|c|}{0.48} & $\begin{array}{c}0.33 \\
28,975\end{array}$ & $\begin{array}{r}0.3 \\
17,6\end{array}$ & $\begin{array}{c}0.34 \\
7,292\end{array}$ & $\begin{array}{c}0.41 \\
21,228\end{array}$ & $\begin{array}{c}0.46 \\
19,743\end{array}$ & $\begin{array}{c}0.46 \\
12,915\end{array}$ & $\begin{array}{c}0.46 \\
12,915\end{array}$ & \\
\hline Observations & Tenure $<2$ & \multicolumn{2}{|c|}{ Tenure $>1 \&<11$} & \multicolumn{2}{|c|}{ Tenure $>10$} & $\begin{array}{l}\text { Public } \\
\text { sector }\end{array}$ & $\begin{array}{l}\text { Private } \\
\text { sector }\end{array}$ & $\begin{array}{c}\text { Permanent } \\
\text { work }\end{array}$ & $\begin{array}{c}\text { Temporary } \\
\text { work }\end{array}$ & Small firm & $\begin{array}{l}\text { Medium } \\
\text { firm }\end{array}$ & Big firm \\
\hline Fixed effects & $\begin{array}{c}-0.122 * * * \\
(0.034)\end{array}$ & \multicolumn{2}{|c|}{$\begin{array}{c}-0.071 * * * \\
(0.026)\end{array}$} & \multicolumn{2}{|c|}{$\begin{array}{l}-0.054 * \\
(0.028)\end{array}$} & $\begin{array}{c}-0.059 * * \\
(0.029)\end{array}$ & $\begin{array}{c}-0.090 * * * \\
(0.020)\end{array}$ & $\begin{array}{c}-0.068^{* * *} \\
(0.019)\end{array}$ & $\begin{array}{c}-0.137 * * * \\
(0.039)\end{array}$ & $\begin{array}{l}-0.037 \\
(0.043)\end{array}$ & $\begin{array}{c}-0.115 * * * \\
(0.024)\end{array}$ & $\begin{array}{c}-0.060^{* *} \\
(0.027)\end{array}$ \\
\hline R-squared & 0.38 & \multicolumn{2}{|l|}{0.44} & \multicolumn{2}{|c|}{0.45} & 0.50 & 0.41 & 0.46 & 0.35 & 0.33 & 0.45 & 0.43 \\
\hline FE- 2SLS & $\begin{array}{l}-0.092 * \\
(0.056)\end{array}$ & \multicolumn{2}{|c|}{$\begin{array}{c}-0.095^{* *} \\
(0.043)\end{array}$} & \multicolumn{2}{|c|}{$\begin{array}{l}-0.034 \\
(0.047)\end{array}$} & $\begin{array}{l}-0.047 \\
(0.049)\end{array}$ & $\begin{array}{c}-0.093 * * * \\
(0.033)\end{array}$ & $\begin{array}{c}-0.077 * * \\
(0.031)\end{array}$ & $\begin{array}{l}-0.108 * \\
(0.062)\end{array}$ & $\begin{array}{l}-0.026 \\
(0.068)\end{array}$ & $\begin{array}{c}-0.095 * * \\
(0.038)\end{array}$ & $\begin{array}{l}-0.091^{*} \\
(0.048)\end{array}$ \\
\hline R-squared & 0.38 & \multicolumn{2}{|c|}{0.44} & \multicolumn{2}{|c|}{0.45} & 0.50 & 0.41 & 0.46 & 0.35 & 0.33 & 0.45 & 0.43 \\
\hline Observations & 13,336 & \multicolumn{2}{|c|}{23,031} & \multicolumn{2}{|c|}{17,519} & 18,265 & 35,621 & 43,082 & 10,804 & 8,785 & 24,902 & 20,199 \\
\hline
\end{tabular}

Notes:

a) Robust standard errors in parentheses. *,** and *** represent significance at $10 \%, 5 \%$ and $1 \%$, respectively.

b) Low skill workers refer to individuals with vocational, lower secondary, primary or no education. Medium skill workers refer to individuals with post-secondary (non-tertiary), vocational secondary or secondary education. High skill workers refer to tertiary and higher education attainment.

c) Small firms refer to enterprises with up to 10 employees. Medium firms refer to enterprises with more than 10 and up to 100 employees. Big firms refer to enterprises with more than 100 employees.

d) In FE-2SLS specification, the logarithm of unemployment rate by region in the previous year has been used as an instrument for the logarithm of unemployment rate by region at time t. 
Table 3 The Polish women unemployment elasticity of real hourly wages by worker type

\begin{tabular}{|c|c|c|c|c|c|c|c|c|c|c|c|c|}
\hline & $\begin{array}{c}\text { All } \\
\text { workers }\end{array}$ & $\begin{array}{l}\text { Age } \\
15-29\end{array}$ & \multicolumn{2}{|c|}{$\begin{array}{l}\text { Age } \\
30-44\end{array}$} & $\begin{array}{c}45 \text { and } \\
\text { older }\end{array}$ & $\begin{array}{l}\text { Low } \\
\text { skill }\end{array}$ & $\begin{array}{l}\text { Medium } \\
\text { skill }\end{array}$ & $\begin{array}{l}\text { High } \\
\text { skill }\end{array}$ & Village & $\begin{array}{l}\text { City up to } \\
100 \mathrm{k}\end{array}$ & $\begin{array}{l}\text { City over } \\
100 \mathrm{k}\end{array}$ & \\
\hline Fixed effects & $\begin{array}{c}-0.038 * * \\
(0.016)\end{array}$ & $\begin{array}{c}-0.009 \\
(0.035)\end{array}$ & \multicolumn{2}{|c|}{$\begin{array}{c}-0.068 * * * \\
(0.025)\end{array}$} & $\begin{array}{c}-0.016 \\
(0.026)\end{array}$ & $\begin{array}{c}-0.069 * * * \\
(0.024)\end{array}$ & $\begin{array}{l}-0.014 \\
(0.022)\end{array}$ & $\begin{array}{l}-0.047 \\
(0.037)\end{array}$ & $\begin{array}{c}-0.060 * * \\
(0.026)\end{array}$ & $\begin{array}{l}-0.017 \\
(0.026)\end{array}$ & $\begin{array}{l}-0.056 \\
(0.034)\end{array}$ & \\
\hline R-squared & 0.48 & 0.60 & \multicolumn{2}{|c|}{0.58} & 0.25 & 0.38 & 0.39 & 0.60 & 0.57 & 0.52 & 0.52 & \\
\hline FE- 2SLS & $\begin{array}{l}-0.041 \\
(0.027)\end{array}$ & $\begin{array}{c}-0.016 \\
(0.057)\end{array}$ & \multicolumn{2}{|c|}{$\begin{array}{c}-0.059 \\
(0.041)\end{array}$} & $\begin{array}{c}-0.047 \\
(0.044)\end{array}$ & $\begin{array}{c}-0.100 * * \\
(0.041)\end{array}$ & $\begin{array}{l}-0.004 \\
(0.037)\end{array}$ & $\begin{array}{c}-0.053 \\
(0.062)\end{array}$ & $\begin{array}{c}-0.073 * \\
(0.041)\end{array}$ & $\begin{array}{c}0.001 \\
(0.042)\end{array}$ & $\begin{array}{l}-0.073 \\
(0.062)\end{array}$ & \\
\hline R-squared & 0.48 & 0.60 & \multicolumn{2}{|c|}{0.58} & 0.25 & 0.38 & 0.39 & 0.60 & 0.57 & 0.52 & 0.52 & \\
\hline \multirow[t]{2}{*}{ Observations } & 10,529 & 20,996 & & 513 & 13,840 & 22,863 & 12,335 & 15,769 & 19,136 & 14,133 & 14,133 & \\
\hline & Tenure $<2$ & \multicolumn{2}{|c|}{ Tenure $>1 \&<11$} & \multicolumn{2}{|c|}{ Tenure $>10$} & $\begin{array}{l}\text { Public } \\
\text { sector }\end{array}$ & $\begin{array}{l}\text { Private } \\
\text { sector }\end{array}$ & $\begin{array}{l}\text { Permanent } \\
\text { work }\end{array}$ & $\begin{array}{c}\text { Temporary } \\
\text { work }\end{array}$ & Small firm & $\begin{array}{l}\text { Medium } \\
\text { firm }\end{array}$ & Big firm \\
\hline Fixed effects & $\begin{array}{c}0.039 \\
(0.034)\end{array}$ & \multicolumn{2}{|c|}{$\begin{array}{c}-0.079 * * * \\
(0.026)\end{array}$} & \multicolumn{2}{|c|}{$\begin{array}{l}-0.036 \\
(0.026)\end{array}$} & $\begin{array}{c}-0.001 \\
(0.023)\end{array}$ & $\begin{array}{c}-0.065 * * * \\
(0.023)\end{array}$ & $\begin{array}{c}-0.047 * * * \\
(0.018)\end{array}$ & $\begin{array}{c}-0.024 \\
(0.037)\end{array}$ & $\begin{array}{l}-0.027 \\
(0.037)\end{array}$ & $\begin{array}{c}-0.067 * * * \\
(0.023)\end{array}$ & $\begin{array}{c}0.010 \\
(0.029)\end{array}$ \\
\hline R-squared & 0.47 & \multicolumn{2}{|c|}{0.54} & \multicolumn{2}{|c|}{0.58} & 0.59 & 0.46 & 0.57 & 0.44 & 0.45 & 0.61 & 0.51 \\
\hline FE- 2SLS & $\begin{array}{c}-0.042 \\
(0.057)\end{array}$ & \multicolumn{2}{|c|}{$\begin{array}{c}-0.062 \\
(0.043)\end{array}$} & \multicolumn{2}{|c|}{$\begin{array}{c}-0.010 \\
(0.042)\end{array}$} & $\begin{array}{c}0.017 \\
(0.038)\end{array}$ & $\begin{array}{c}-0.087 * * \\
(0.037)\end{array}$ & $\begin{array}{c}-0.025 \\
(0.030)\end{array}$ & $\begin{array}{c}-0.134^{* *} \\
(0.063)\end{array}$ & $\begin{array}{l}-0.079 \\
(0.060)\end{array}$ & $\begin{array}{c}-0.056 \\
(0.038)\end{array}$ & $\begin{array}{c}0.009 \\
(0.049)\end{array}$ \\
\hline R-squared & 0.47 & \multicolumn{2}{|c|}{0.54} & \multicolumn{2}{|c|}{0.58} & 0.59 & 0.46 & 0.57 & 0.44 & 0.45 & 0.61 & 0.51 \\
\hline Observations & 10,322 & \multicolumn{2}{|c|}{19,885} & \multicolumn{2}{|c|}{18,831} & 25,047 & 23,991 & 40,038 & 9,000 & 9,025 & 24,532 & 15,481 \\
\hline
\end{tabular}

Notes:

a) Robust standard errors in parentheses. *,** and *** represent significance at $10 \%, 5 \%$ and $1 \%$, respectively.

b) Low skill workers refer to individuals with vocational, lower secondary, primary or no education. Medium skill workers refer to individuals with post-secondary (non-tertiary), vocational secondary or secondary education. High skill workers refer to tertiary and higher education attainment.

c) Small firms refer to enterprises with up to 10 employees. Medium firms refer to enterprises with more than 10 and up to 100 employees. Big firms refer to enterprises with more than 100 employees.

d) In FE-2SLS specification, the logarithm of unemployment rate by region in the previous year has been used as an instrument for the logarithm of unemployment rate by region at time t. 
Table 4 The spatial Polish unemployment elasticity of real hourly wages by worker type - contiguity weight matrix

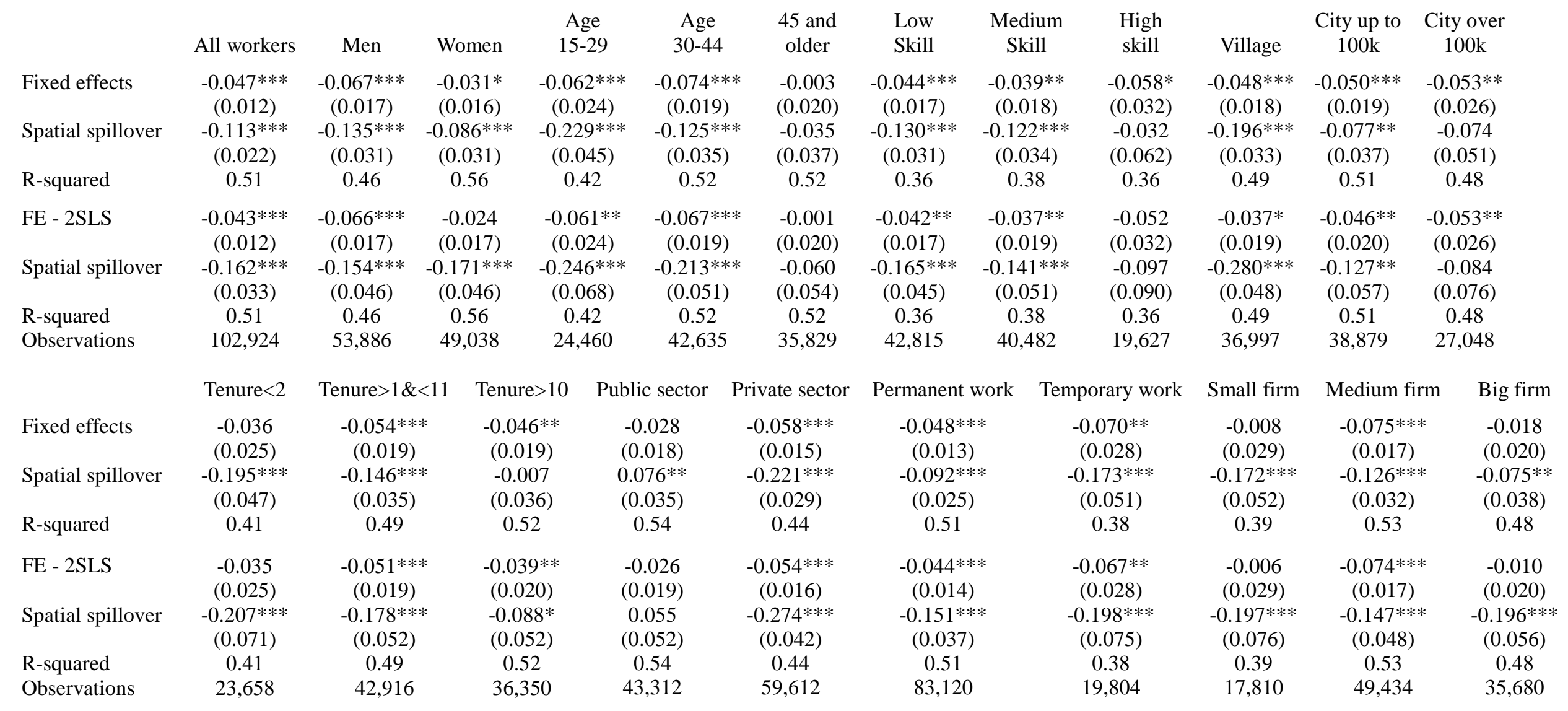

Notes:

a) Robust standard errors in parentheses. *, ** and *** represent significance at $10 \%, 5 \%$ and $1 \%$, respectively.

b) Low skill workers refer to individuals with vocational, lower secondary, primary or no education. Medium skill workers refer to individuals with post-secondary (non-tertiary), vocational secondary or secondary education. High skill workers refer to tertiary and higher education attainment.

c) Small firms refer to enterprises with up to 10 employees. Medium firms refer to enterprises with more than 10 and up to 100 employees. Big firms refer to enterprises with more than 100 employees.

d) In FE-2SLS specification, the instruments used are the logarithm of unemployment rate by region in the previous year and the logarithm of spatial spillover by region in the previous year. 
Table 5 The spatial Polish men unemployment elasticity of real hourly wages by worker type - contiguity weight matrix

\begin{tabular}{|c|c|c|c|c|c|c|c|c|c|c|c|c|}
\hline \multirow[b]{2}{*}{ Fixed effects } & All workers & $\begin{array}{c}\text { Age } \\
15-29\end{array}$ & $\begin{array}{c}\text { Age } \\
30-44\end{array}$ & $\begin{array}{l}45 \text { and } \\
\text { older }\end{array}$ & $\begin{array}{l}\text { Low } \\
\text { skill }\end{array}$ & $\begin{array}{l}\text { Medium } \\
\text { skill }\end{array}$ & $\begin{array}{l}\text { High } \\
\text { skill }\end{array}$ & Village & $\begin{array}{l}\text { City up to } \\
100 \mathrm{k}\end{array}$ & \multicolumn{3}{|l|}{$\begin{array}{c}\text { City over } \\
100 \mathrm{k}\end{array}$} \\
\hline & $\begin{array}{c}-0.067 * * * \\
(0.017)\end{array}$ & $\begin{array}{c}-0.126 * * * \\
(0.032)\end{array}$ & $\begin{array}{c}-0.089 * * * \\
(0.027)\end{array}$ & $\begin{array}{c}-0.005 \\
(0.029)\end{array}$ & $\begin{array}{c}-0.038^{*} \\
(0.021)\end{array}$ & $\begin{array}{c}-0.086^{* * *} \\
(0.029)\end{array}$ & $\begin{array}{l}-0.099 * \\
(0.055)\end{array}$ & $\begin{array}{c}-0.058 * * \\
(0.025)\end{array}$ & $\begin{array}{c}-0.092 * * * \\
(0.028)\end{array}$ & $\begin{array}{c}-0.064 \\
(0.040)\end{array}$ & & \\
\hline Spatial spillover & $\begin{array}{c}-0.135^{* * * *} \\
(0.031)\end{array}$ & $\begin{array}{c}-0.300 * * * \\
(0.060)\end{array}$ & $\begin{array}{c}-0.161 * * * \\
(0.050)\end{array}$ & $\begin{array}{c}0.001 \\
(0.053)\end{array}$ & $\begin{array}{c}-0.129 * * * \\
(0.039)\end{array}$ & $\begin{array}{c}-0.120 * * \\
(0.054)\end{array}$ & $\begin{array}{l}-0.129 \\
(0.106)\end{array}$ & $\begin{array}{c}-0.207 * * * \\
(0.046)\end{array}$ & $\begin{array}{l}-0.090^{*} \\
(0.054)\end{array}$ & $\begin{array}{l}-0.098 \\
(0.075)\end{array}$ & & \\
\hline R-squared & 0.46 & 0.39 & 0.46 & 0.48 & 0.33 & 0.36 & 0.34 & 0.41 & 0.46 & 0.46 & & \\
\hline FE - 2SLS & $\begin{array}{c}-0.066 * * * \\
(0.017)\end{array}$ & $\begin{array}{c}-0.126 * * * \\
(0.032)\end{array}$ & $\begin{array}{c}-0.085 * * * \\
(0.027)\end{array}$ & $\begin{array}{l}-0.004 \\
(0.029)\end{array}$ & $\begin{array}{c}-0.037 * \\
(0.021)\end{array}$ & $\begin{array}{c}-0.086^{* * *} \\
(0.030)\end{array}$ & $\begin{array}{c}-0.100 * \\
(0.056)\end{array}$ & $\begin{array}{c}-0.048^{*} \\
(0.026)\end{array}$ & $\begin{array}{c}-0.089 * * * \\
(0.028)\end{array}$ & $\begin{array}{l}-0.061 \\
(0.040)\end{array}$ & & \\
\hline Spatial spillover & $\begin{array}{c}-0.154 * * * \\
(0.046)\end{array}$ & $\begin{array}{c}-0.301 * * * \\
(0.089)\end{array}$ & $\begin{array}{c}-0.211 * * * \\
(0.074)\end{array}$ & $\begin{array}{c}-0.002 \\
(0.078)\end{array}$ & $\begin{array}{c}-0.150^{* *} \\
(0.058)\end{array}$ & $\begin{array}{l}-0.126 \\
(0.080)\end{array}$ & $\begin{array}{l}-0.118 \\
(0.152)\end{array}$ & $\begin{array}{c}-0.282 * * * \\
(0.066)\end{array}$ & $\begin{array}{l}-0.134 \\
(0.083)\end{array}$ & $\begin{array}{c}0.020 \\
(0.112)\end{array}$ & & \\
\hline \multirow[t]{2}{*}{ Observations } & $\begin{array}{c}0.46 \\
53,886\end{array}$ & $\begin{array}{c}0.39 \\
13,931\end{array}$ & $\begin{array}{c}0.46 \\
21639\end{array}$ & 0.48 & 0.33 & $\begin{array}{c}0.36 \\
17,619\end{array}$ & $\begin{array}{c}0.34 \\
7,292\end{array}$ & 0.41 & $\begin{array}{c}0.46 \\
19,743\end{array}$ & $\begin{array}{c}0.46 \\
12,915\end{array}$ & & \\
\hline & Tenure $<2$ & Tenure $>1 \&<11$ & 11 Tenure $>10$ & \multicolumn{2}{|c|}{ Public sector } & Private sector & Permanent work & \multicolumn{2}{|c|}{ Temporary work } & Small firm & Medium firm & Big firm \\
\hline Fixed effects & $\begin{array}{c}-0.113^{* * *} \\
(0.034)\end{array}$ & $\begin{array}{c}-0.057 * * \\
(0.026)\end{array}$ & $\begin{array}{l}-0.051^{*} \\
(0.028)\end{array}$ & & $\begin{array}{l}67 * * \\
029)\end{array}$ & $\begin{array}{c}-0.072 * * * \\
(0.021)\end{array}$ & $\begin{array}{c}-0.058^{* * * *} \\
(0.019)\end{array}$ & & $\begin{array}{l}.128 * * * \\
(0.039)\end{array}$ & $\begin{array}{l}-0.026 \\
(0.043)\end{array}$ & $\begin{array}{c}-0.099 * * * \\
(0.024)\end{array}$ & $\begin{array}{c}-0.055^{* *} \\
(0.028)\end{array}$ \\
\hline Spatial spillover & $\begin{array}{c}-0.144^{* *} \\
(0.066)\end{array}$ & $\begin{array}{c}-0.192 * * * \\
(0.049)\end{array}$ & $\begin{array}{l}-0.037 \\
(0.051)\end{array}$ & & $\begin{array}{l}106^{*} \\
055)\end{array}$ & $\begin{array}{c}-0.236 * * * \\
(0.038)\end{array}$ & $\begin{array}{c}-0.145^{* * *} \\
(0.035)\end{array}$ & & $\begin{array}{l}-0.085 \\
(0.072)\end{array}$ & $\begin{array}{l}-0.119 \\
(0.079)\end{array}$ & $\begin{array}{c}-0.179 * * * \\
(0.045)\end{array}$ & $\begin{array}{l}-0.081 \\
(0.052)\end{array}$ \\
\hline R-squared & 0.38 & 0.44 & 0.45 & & .50 & 0.41 & 0.46 & & 0.35 & 0.33 & 0.45 & 0.43 \\
\hline FE - 2SLS & $\begin{array}{c}-0.113 * * * \\
(0.035)\end{array}$ & $\begin{array}{c}-0.056 * * \\
(0.026)\end{array}$ & $\begin{array}{l}-0.047 \\
(0.028)\end{array}$ & & $\begin{array}{l}67 * * \\
029)\end{array}$ & $\begin{array}{c}-0.070 * * * \\
(0.021)\end{array}$ & $\begin{array}{c}-0.056 * * * \\
(0.019)\end{array}$ & & $\begin{array}{l}.130 * * * \\
(0.040)\end{array}$ & $\begin{array}{l}-0.028 \\
(0.043)\end{array}$ & $\begin{array}{c}-0.103 * * * \\
(0.025)\end{array}$ & $\begin{array}{l}-0.048^{*} \\
(0.028)\end{array}$ \\
\hline Spatial spillover & $\begin{array}{l}-0.136 \\
(0.098)\end{array}$ & $\begin{array}{c}-0.197 * * * \\
(0.073)\end{array}$ & $\begin{array}{l}-0.082 \\
(0.074)\end{array}$ & & $\begin{array}{l}115 \\
081)\end{array}$ & $\begin{array}{c}-0.261^{* * *} \\
(0.057)\end{array}$ & $\begin{array}{c}-0.173 * * * \\
(0.052)\end{array}$ & & $\begin{array}{l}-0.070 \\
(0.105)\end{array}$ & $\begin{array}{c}-0.102 \\
(0.114)\end{array}$ & $\begin{array}{c}-0.137 * * \\
(0.067)\end{array}$ & $\begin{array}{c}-0.213 * * * \\
(0.076)\end{array}$ \\
\hline R-squared & 0.38 & 0.44 & 0.45 & & .50 & 0.41 & 0.46 & & 0.35 & 0.33 & 0.45 & 0.43 \\
\hline Observations & 13,336 & 23,031 & 17,519 & & ,265 & 35,621 & 43,082 & & 10,804 & 8,785 & 24,902 & 20,199 \\
\hline
\end{tabular}

Notes:

a) Robust standard errors in parentheses. *, ** and *** represent significance at $10 \%, 5 \%$ and $1 \%$, respectively.

b) Low skill workers refer to individuals with vocational, lower secondary, primary or no education. Medium skill workers refer to individuals with post-secondary (non-tertiary), vocational secondary or secondary education. High skill workers refer to tertiary and higher education attainment.

c) Small firms refer to enterprises with up to 10 employees. Medium firms refer to enterprises with more than 10 and up to 100 employees. Big firms refer to enterprises with more than 100 employees.

d) In FE-2SLS specification, the instruments used are the logarithm of unemployment rate by region in the previous year and the logarithm of spatial spillover by region in the previous year. 
Table 6 The spatial Polish women unemployment elasticity of real hourly wages by worker type - contiguity weight matrix

\begin{tabular}{lcccccccccc} 
& & Age & Age & 45 and & Low & Medium & High & \multicolumn{2}{c}{ City up to } & City over \\
& All workers & $15-29$ & $30-44$ & older & skill & skill & skill & Village & $100 \mathrm{k}$ & $100 \mathrm{k}$ \\
Fixed effects & $-0.031^{*}$ & 0.001 & $-0.062^{* *}$ & -0.009 & $-0.061^{* *}$ & -0.004 & -0.049 & -0.037 & -0.011 & -0.056 \\
& $(0.016)$ & $(0.035)$ & $(0.025)$ & $(0.027)$ & $(0.025)$ & $(0.023)$ & $(0.038)$ & $(0.027)$ & $(0.026)$ & $(0.034)$ \\
Spatial spillover & $-0.086^{* * *}$ & $-0.136^{* *}$ & -0.070 & -0.078 & $-0.136^{* * *}$ & $-0.115^{* * *}$ & 0.017 & $-0.158^{* * *}$ & -0.071 & -0.035 \\
& $(0.031)$ & $(0.067)$ & $(0.046)$ & $(0.050)$ & $(0.044)$ & $(0.043)$ & $(0.075)$ & $(0.047)$ & $(0.050)$ & $(0.068)$ \\
R-squared & 0.56 & 0.48 & 0.60 & 0.58 & 0.25 & 0.38 & 0.39 & 0.60 & 0.57 & 0.52 \\
FE - 2SLS & -0.024 & 0.006 & $-0.052^{* *}$ & -0.005 & $-0.058^{* *}$ & -0.001 & -0.038 & -0.025 & -0.005 & -0.056 \\
& $(0.017)$ & $(0.036)$ & $(0.026)$ & $(0.027)$ & $(0.025)$ & $(0.023)$ & $(0.039)$ & $(0.028)$ & $(0.027)$ & $(0.034)$ \\
Spatial spillover & $-0.171^{* * *}$ & $-0.197^{*}$ & $-0.186^{* * *}$ & -0.123 & $-0.200^{* * *}$ & $-0.153^{* *}$ & -0.094 & $-0.244^{* * *}$ & $-0.137 *$ & $-0.179^{*}$ \\
& $(0.046)$ & $(0.102)$ & $(0.069)$ & $(0.075)$ & $(0.066)$ & $(0.064)$ & $(0.110)$ & $(0.070)$ & $(0.077)$ & $(0.104)$ \\
R-squared & 0.56 & 0.48 & 0.60 & 0.58 & 0.25 & 0.38 & 0.39 & 0.60 & 0.57 & 0.52 \\
Observations & 49,038 & 10,529 & 20,996 & 17,513 & 13,840 & 22,863 & 12,335 & 15,769 & 19,136 & 14,133
\end{tabular}

Tenure $<2 \quad$ Tenure $>1 \&<11 \quad$ Tenure $>10 \quad$ Public sector $\quad$ Private sector $\quad$ Permanent work $\quad$ Temporary work $\quad$ Small firm $\quad$ Medium firm $\quad$ Big firm

\begin{tabular}{|c|c|c|c|c|c|c|c|c|c|c|}
\hline Fixed effects & $\begin{array}{c}0.056 \\
(0.035)\end{array}$ & $\begin{array}{c}-0.073 * * * \\
(0.026)\end{array}$ & $\begin{array}{c}-0.038 \\
(0.026)\end{array}$ & $\begin{array}{l}-0.005 \\
(0.023)\end{array}$ & $\begin{array}{c}-0.050 * * \\
(0.023)\end{array}$ & $\begin{array}{c}-0.045^{* *} \\
(0.018)\end{array}$ & $\begin{array}{c}0.002 \\
(0.038)\end{array}$ & $\begin{array}{c}-0.007 \\
(0.038)\end{array}$ & $\begin{array}{c}-0.061 * * * \\
(0.023)\end{array}$ & $\begin{array}{c}0.015 \\
(0.029)\end{array}$ \\
\hline Spatial spillover & $\begin{array}{c}-0.241 * * * \\
(0.065)\end{array}$ & $\begin{array}{c}-0.080 \\
(0.049)\end{array}$ & $\begin{array}{c}0.013 \\
(0.049)\end{array}$ & $\begin{array}{c}0.038 \\
(0.045)\end{array}$ & $\begin{array}{c}-0.198 * * * \\
(0.042)\end{array}$ & $\begin{array}{c}-0.028 \\
(0.035)\end{array}$ & $\begin{array}{c}-0.284 * * * \\
(0.070)\end{array}$ & $\begin{array}{c}-0.214^{* * *} \\
(0.068)\end{array}$ & $\begin{array}{c}-0.067 \\
(0.044)\end{array}$ & $\begin{array}{l}-0.065 \\
(0.054)\end{array}$ \\
\hline R-squared & 0.47 & 0.54 & 0.58 & 0.59 & 0.46 & 0.57 & 0.44 & 0.45 & 0.61 & 0.51 \\
\hline FE - 2SLS & $\begin{array}{l}0.061 * \\
(0.035)\end{array}$ & $\begin{array}{c}-0.068 * * \\
(0.027)\end{array}$ & $\begin{array}{c}-0.027 \\
(0.027)\end{array}$ & $\begin{array}{c}0.000 \\
(0.024)\end{array}$ & $\begin{array}{c}-0.043 * \\
(0.023)\end{array}$ & $\begin{array}{c}-0.038 * * \\
(0.019)\end{array}$ & $\begin{array}{c}0.010 \\
(0.039)\end{array}$ & $\begin{array}{c}-0.000 \\
(0.039)\end{array}$ & $\begin{array}{c}-0.054 * * \\
(0.024)\end{array}$ & $\begin{array}{c}0.024 \\
(0.030)\end{array}$ \\
\hline Spatial spillover & $\begin{array}{c}-0.300 * * * \\
(0.100)\end{array}$ & $\begin{array}{c}-0.140^{*} \\
(0.074)\end{array}$ & $\begin{array}{c}-0.098 \\
(0.072)\end{array}$ & $\begin{array}{c}-0.013 \\
(0.067)\end{array}$ & $\begin{array}{c}-0.291 * * * \\
(0.063)\end{array}$ & $\begin{array}{c}-0.116^{* *} \\
(0.052)\end{array}$ & $\begin{array}{c}-0.373 * * * \\
(0.106)\end{array}$ & $\begin{array}{c}-0.284 * * * \\
(0.101)\end{array}$ & $\begin{array}{c}-0.152^{* *} \\
(0.066)\end{array}$ & $\begin{array}{c}-0.189 * * \\
(0.080)\end{array}$ \\
\hline R-squared & 0.47 & 0.54 & 0.58 & 0.59 & 0.46 & 0.57 & 0.44 & 0.45 & 0.61 & 0.51 \\
\hline Observations & 10,322 & 19,885 & 18,831 & 25,047 & 23,991 & 40,038 & 9,000 & 9,025 & 24,532 & 15,481 \\
\hline
\end{tabular}

Notes:

a) Robust standard errors in parentheses. *, ** and *** represent significance at $10 \%, 5 \%$ and $1 \%$, respectively.

b) Low skill workers refer to individuals with vocational, lower secondary, primary or no education. Medium skill workers refer to individuals with post-secondary (non-tertiary), vocational secondary or secondary education. High skill workers refer to tertiary and higher education attainment.

c) Small firms refer to enterprises with up to 10 employees. Medium firms refer to enterprises with more than 10 and up to 100 employees. Big firms refer to enterprises with more than 100 employees.

d) In FE-2SLS specification, the instruments used are the logarithm of unemployment rate by region in the previous year and the logarithm of spatial spillover by region in the previous year. 
Table 7 The spatial Polish unemployment elasticity of real hourly wages by worker type - inverse distance weight matrix

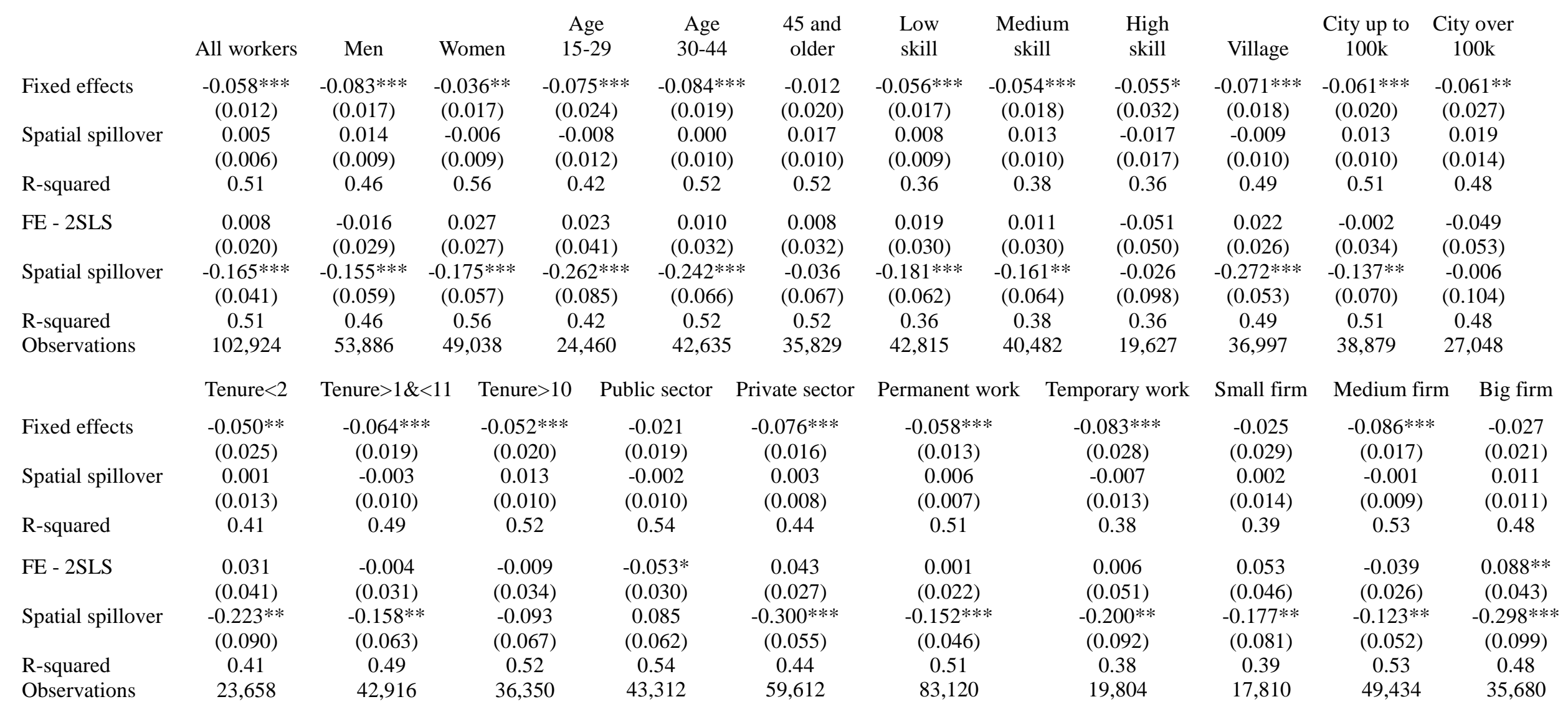

Notes:

a) Robust standard errors in parentheses. * ** and *** represent significance at $10 \%, 5 \%$ and $1 \%$, respectively.

b) Low skill workers refer to individuals with vocational, lower secondary, primary or no education. Medium skill workers refer to individuals with post-secondary (non-tertiary), vocational secondary or secondary education. High skill workers refer to tertiary and higher education attainment.

c) Small firms refer to enterprises with up to 10 employees. Medium firms refer to enterprises with more than 10 and up to 100 employees. Big firms refer to enterprises with more than 100 employees.

d) In FE-2SLS specification, the instruments used are the logarithm of unemployment rate by region in the previous year and the logarithm of spatial spillover by region in the previous year. 
Table 8 The spatial Polish unemployment elasticity of real hourly wages by worker type - inverse square distance weight matrix

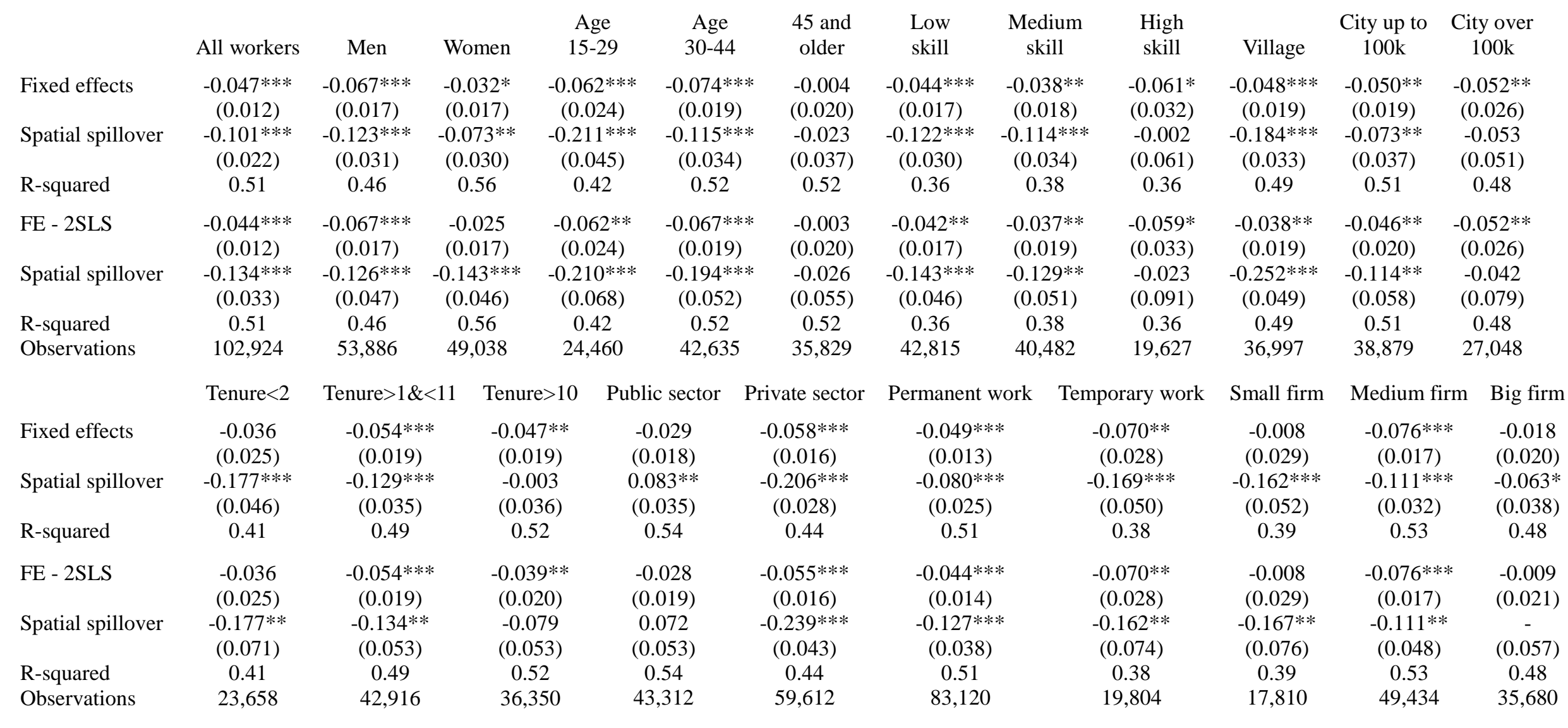

Notes:

a) Robust standard errors in parentheses. ${ }^{*}, * *$ and $* * *$ represent significance at $10 \%, 5 \%$ and $1 \%$, respectively.

b) Low skill workers refer to individuals with vocational, lower secondary, primary or no education. Medium skill workers refer to individuals with post-secondary (non-tertiary), vocational secondary or secondary education. High skill workers refer to tertiary and higher education attainment.

c) Small firms refer to enterprises with up to 10 employees. Medium firms refer to enterprises with more than 10 and up to 100 employees. Big firms refer to enterprises with more than 100 employees.

d) In FE-2SLS specification, the instruments used are the logarithm of unemployment rate by region in the previous year and the logarithm of spatial spillover by region in the previous year. 
Table 9 The spatial Polish men unemployment elasticity of real hourly wages by worker type - gender-specific unemployment rate- contiguity weight matrix

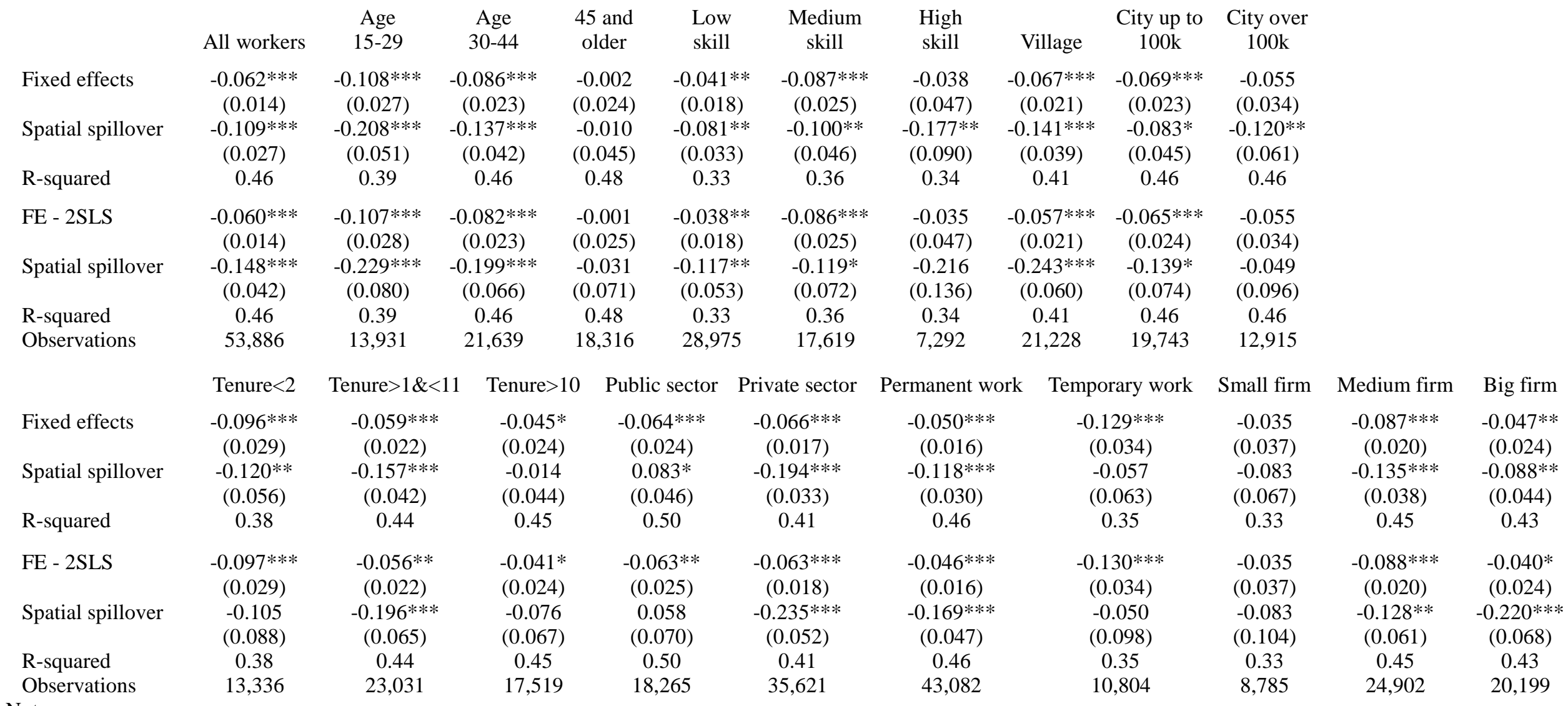

Notes:

a) Robust standard errors in parentheses. *, ** and *** represent significance at $10 \%, 5 \%$ and $1 \%$, respectively.

b) Low skill workers refer to individuals with vocational, lower secondary, primary or no education. Medium skill workers refer to individuals with post-secondary (non-tertiary),

vocational secondary or secondary education. High skill workers refer to tertiary and higher education attainment.

c) Small firms refer to enterprises with up to 10 employees. Medium firms refer to enterprises with more than 10 and up to 100 employees. Big firms refer to enterprises with more than 100 employees.

d) In FE-2SLS specification, the instruments used are the logarithm of unemployment rate by region in the previous year and the logarithm of spatial spillover by region in the previous year. 
Table 10 The spatial Polish women unemployment elasticity of real hourly wages by worker type - gender-specific unemployment rate contiguity weight matrix

\begin{tabular}{|c|c|c|c|c|c|c|c|c|c|c|}
\hline & All workers & $\begin{array}{l}\text { Age } \\
15-29\end{array}$ & $\begin{array}{c}\text { Age } \\
30-44\end{array}$ & $\begin{array}{c}45 \text { and } \\
\text { older }\end{array}$ & $\begin{array}{l}\text { Low } \\
\text { skill }\end{array}$ & $\begin{array}{l}\text { Medium } \\
\text { skill }\end{array}$ & $\begin{array}{l}\text { High } \\
\text { skill }\end{array}$ & Village & $\begin{array}{l}\text { City up to } \\
100 \mathrm{k}\end{array}$ & $\begin{array}{c}\text { City over } \\
100 \mathrm{k}\end{array}$ \\
\hline Fixed effects & $\begin{array}{c}-0.024 \\
(0.016)\end{array}$ & $\begin{array}{c}-0.002 \\
(0.034)\end{array}$ & $\begin{array}{c}-0.046^{*} \\
(0.025)\end{array}$ & $\begin{array}{c}-0.010 \\
(0.027)\end{array}$ & $\begin{array}{c}-0.059 * * \\
(0.024)\end{array}$ & $\begin{array}{c}0.003 \\
(0.022)\end{array}$ & $\begin{array}{l}-0.043 \\
(0.038)\end{array}$ & $\begin{array}{l}-0.019 \\
(0.026)\end{array}$ & $\begin{array}{c}-0.020 \\
(0.026)\end{array}$ & $\begin{array}{l}-0.048 \\
(0.035)\end{array}$ \\
\hline Spatial spillover & $\begin{array}{c}-0.100^{* * *} \\
(0.033)\end{array}$ & $\begin{array}{c}-0.160 * * \\
(0.071)\end{array}$ & $\begin{array}{l}-0.074 \\
(0.049)\end{array}$ & $\begin{array}{l}-0.086 \\
(0.054)\end{array}$ & $\begin{array}{c}-0.146^{* * *} \\
(0.047)\end{array}$ & $\begin{array}{c}-0.129 * * * \\
(0.045)\end{array}$ & $\begin{array}{c}0.003 \\
(0.079)\end{array}$ & $\begin{array}{c}-0.186 * * * \\
(0.051)\end{array}$ & $\begin{array}{l}-0.070 \\
(0.053)\end{array}$ & $\begin{array}{l}-0.042 \\
(0.074)\end{array}$ \\
\hline R-squared & 0.56 & 0.48 & 0.60 & 0.58 & 0.25 & 0.38 & 0.39 & 0.60 & 0.57 & 0.52 \\
\hline FE - 2SLS & $\begin{array}{c}-0.020 \\
(0.016)\end{array}$ & $\begin{array}{l}-0.000 \\
(0.034)\end{array}$ & $\begin{array}{c}-0.039 \\
(0.025)\end{array}$ & $\begin{array}{l}-0.009 \\
(0.027)\end{array}$ & $\begin{array}{c}-0.058^{* *} \\
(0.024)\end{array}$ & $\begin{array}{c}0.005 \\
(0.022)\end{array}$ & $\begin{array}{c}-0.034 \\
(0.038)\end{array}$ & $\begin{array}{c}-0.010 \\
(0.027)\end{array}$ & $\begin{array}{l}-0.017 \\
(0.026)\end{array}$ & $\begin{array}{l}-0.054 \\
(0.035)\end{array}$ \\
\hline Spatial spillover & $\begin{array}{c}-0.192^{* * *} \\
(0.052)\end{array}$ & $\begin{array}{l}-0.218^{*} \\
(0.115)\end{array}$ & $\begin{array}{c}-0.232 * * * \\
(0.078)\end{array}$ & $\begin{array}{l}-0.092 \\
(0.083)\end{array}$ & $\begin{array}{c}-0.178 * * \\
(0.075)\end{array}$ & $\begin{array}{c}-0.164 * * \\
(0.074)\end{array}$ & $\begin{array}{c}-0.159 \\
(0.120)\end{array}$ & $\begin{array}{c}-0.270 * * * \\
(0.077)\end{array}$ & $\begin{array}{l}-0.141 \\
(0.087)\end{array}$ & $\begin{array}{l}-0.174 \\
(0.125)\end{array}$ \\
\hline R-squared & 0.56 & 0.48 & 0.60 & 0.58 & 0.25 & 0.38 & 0.39 & 0.60 & 0.57 & 0.52 \\
\hline Observations & 49,038 & 10,529 & 20,996 & 17,513 & 13,840 & 22,863 & 12,335 & 15,769 & 19,136 & 14,133 \\
\hline
\end{tabular}

Tenure $<2 \quad$ Tenure $>1 \&<11 \quad$ Tenure $>10 \quad$ Public sector Private sector Permanent work Temporary work Small firm Medium firm Big firm

\begin{tabular}{|c|c|c|c|c|c|c|c|c|c|c|}
\hline Fixed effects & $\begin{array}{c}0.039 \\
(0.034)\end{array}$ & $\begin{array}{c}-0.063 * * \\
(0.026)\end{array}$ & $\begin{array}{l}-0.022 \\
(0.026)\end{array}$ & $\begin{array}{c}0.010 \\
(0.023)\end{array}$ & $\begin{array}{c}-0.049 * * \\
(0.022)\end{array}$ & $\begin{array}{l}-0.033^{*} \\
(0.018)\end{array}$ & $\begin{array}{l}-0.012 \\
(0.036)\end{array}$ & $\begin{array}{l}-0.007 \\
(0.036)\end{array}$ & $\begin{array}{c}-0.050 * * \\
(0.023)\end{array}$ & $\begin{array}{c}0.016 \\
(0.029)\end{array}$ \\
\hline Spatial spillover & $\begin{array}{c}-0.224^{* * *} \\
(0.070)\end{array}$ & $\begin{array}{c}-0.113^{* *} \\
(0.051)\end{array}$ & $\begin{array}{c}0.000 \\
(0.053)\end{array}$ & $\begin{array}{c}0.025 \\
(0.048)\end{array}$ & $\begin{array}{c}-0.214^{* * *} \\
(0.044)\end{array}$ & $\begin{array}{l}-0.040 \\
(0.037)\end{array}$ & $\begin{array}{c}-0.309 * * * \\
(0.073)\end{array}$ & $\begin{array}{c}-0.213^{* * * *} \\
(0.071)\end{array}$ & $\begin{array}{l}-0.085^{*} \\
(0.047)\end{array}$ & $\begin{array}{l}-0.070 \\
(0.058)\end{array}$ \\
\hline R-squared & 0.47 & 0.54 & 0.58 & 0.59 & 0.46 & 0.57 & 0.44 & 0.45 & 0.61 & 0.51 \\
\hline FE - 2SLS & $\begin{array}{c}0.042 \\
(0.034)\end{array}$ & $\begin{array}{c}-0.062 * * \\
(0.026)\end{array}$ & $\begin{array}{l}-0.016 \\
(0.026)\end{array}$ & $\begin{array}{c}0.014 \\
(0.023)\end{array}$ & $\begin{array}{c}-0.047 * * \\
(0.022)\end{array}$ & $\begin{array}{l}-0.029 \\
(0.018)\end{array}$ & $\begin{array}{l}-0.008 \\
(0.037)\end{array}$ & $\begin{array}{l}-0.004 \\
(0.036)\end{array}$ & $\begin{array}{l}-0.045^{*} \\
(0.023)\end{array}$ & $\begin{array}{c}0.020 \\
(0.029)\end{array}$ \\
\hline Spatial spillover & $\begin{array}{c}-0.329 * * * \\
(0.112)\end{array}$ & $\begin{array}{l}-0.157^{*} \\
(0.081)\end{array}$ & $\begin{array}{l}-0.114 \\
(0.083)\end{array}$ & $\begin{array}{l}-0.052 \\
(0.078)\end{array}$ & $\begin{array}{c}-0.286^{* * *} \\
(0.069)\end{array}$ & $\begin{array}{c}-0.138 * * \\
(0.060)\end{array}$ & $\begin{array}{c}-0.382^{* * * *} \\
(0.110)\end{array}$ & $\begin{array}{c}-0.273^{* *} \\
(0.109)\end{array}$ & $\begin{array}{c}-0.179 * * \\
(0.074)\end{array}$ & $\begin{array}{c}-0.199 * * \\
(0.093)\end{array}$ \\
\hline $\begin{array}{l}\text { R-squared } \\
\text { Observations }\end{array}$ & $\begin{array}{c}0.47 \\
10,322\end{array}$ & $\begin{array}{c}0.54 \\
19.885\end{array}$ & $\begin{array}{c}0.58 \\
18.831\end{array}$ & $\begin{array}{c}0.59 \\
25,047\end{array}$ & $\begin{array}{c}0.46 \\
23,991\end{array}$ & $\begin{array}{c}0.57 \\
40.038\end{array}$ & $\begin{array}{c}0.44 \\
9.000\end{array}$ & $\begin{array}{c}0.45 \\
9,025\end{array}$ & $\begin{array}{c}0.61 \\
24,532\end{array}$ & $\begin{array}{c}0.51 \\
15,481\end{array}$ \\
\hline
\end{tabular}

Notes:

a) Robust standard errors in parentheses. *,** and $* * *$ represent significance at $10 \%, 5 \%$ and $1 \%$, respectively.

b) Low skill workers refer to individuals with vocational, lower secondary, primary or no education. Medium skill workers refer to individuals with post-secondary (non-tertiary),

vocational secondary or secondary education. High skill workers refer to tertiary and higher education attainment.

c) Small firms refer to enterprises with up to 10 employees. Medium firms refer to enterprises with more than 10 and up to 100 employees. Big firms refer to enterprises with more than 100 employees.

d) In FE-2SLS specification, the instruments used are the logarithm of unemployment rate by region in the previous year and the logarithm of spatial spillover by region in the previous year. 